Trinity University

Digital Commons @ Trinity

School of Business Faculty Research

School of Business

$8-2013$

\title{
Does a Lack of Choice Lead to Lower Quality?: Evidence from Auditor Competition and Client Restatements
}

Nathan J. Newton

Dechun Wang

Michael S. Wilkins

Trinity University, mike.wilkins@trinity.edu

Follow this and additional works at: https://digitalcommons.trinity.edu/busadmin_faculty

Part of the Accounting Commons

\section{Repository Citation}

Newton, N. J., Wang, D., \& Wilkins, M. S. (2013). Does a lack of choice lead to lower quality? Evidence from auditor competition and client restatements. Auditing: A Journal Of Practice \& Theory, 32(3), 31-67. doi: 10.2308/ajpt-50461

This Article is brought to you for free and open access by the School of Business at Digital Commons @ Trinity. It has been accepted for inclusion in School of Business Faculty Research by an authorized administrator of Digital Commons @ Trinity. For more information, please contact jcostanz@trinity.edu. 


\title{
Does a Lack of Choice Lead to Lower Quality? Evidence from Auditor Competition and Client Restatements
}

\begin{abstract}
Nathan J. Newton, Dechun Wang, and Michael S. Wilkins
SUMMARY: We examine the relationship between auditor competition and the likelihood of financial restatements that occur as a result of failures in the application of generally accepted accounting principles (GAAP). Policy makers and audit market participants have expressed concern that the current level of auditor competition is low, resulting in a negative impact on audit quality. However, we find that restatements are more likely to occur in metropolitan statistical areas (MSAs) that have higher auditor competition. The association between audit market competition and restatements is statistically and economically significant. Our finding of a positive relationship between the likelihood of restatement and audit market competition is relevant to the ongoing debate regarding audit quality and the concentration of audit markets.
\end{abstract}

Keywords: auditor competition; audit markets; restatements.

\section{INTRODUCTION}

ince the late 1980s, top-tier audit firms have undergone several rounds of consolidation, resulting in fewer options for client companies. In the current national audit market, audit services are dominated by four large, international firms. ${ }^{1}$ Most research to date suggests that these firms provide higher-quality audits (e.g., Khurana and Raman 2004; Behn et al. 2008). Audit quality also tends to be higher when audits are performed by firms or offices that have

Nathan J. Newton is an Assistant Professor at the University of Missouri-Columbia, Dechun Wang is an Associate Professor at Texas A\&M University, and Michael S. Wilkins is a Professor at Trinity University.

We are grateful for helpful comments from Kathleen Bentley, Neil Fargher, Rebecca Files, Chris Hogan, Brian Mayhew, Jaime Schmidt, Nathan Sharp, Sarah Stein, Vicky Yu, and workshop participants at Texas A\&M University, the 2012 Auditing Section Midyear Conference, and the 2012 AAA Annual Meeting.

Editor's note: Accepted by Debra C. Jeter.

Submitted: April 2012

Accepted: March 2013

Published Online: March 2013

\footnotetext{
1 The Big 4 audit firms audit 78 percent of the observations in our sample and 66 percent of the observations listed on Audit Analytics between 2000 and 2009. The U.S. Government Accountability Office (GAO 2008) indicates that the Big 4 audit firms audited 87 percent of firms with at least $\$ 100$ million in revenue in 2006.
} 
industry expertise (e.g., Balsam et al. 2003; Reichelt and Wang 2010) and/or by offices that are large (e.g., Francis and Yu 2009; Choi et al. 2010; Francis et al. 2013)—conditions that exist almost exclusively among the Big 4 firms. Despite evidence that the dominant accounting firms tend to provide the best audits, regulators and market participants have expressed concern that audit quality may be impaired when audit markets are concentrated. Our purpose in this paper is to address this issue empirically by investigating how competition among audit firms in local markets affects the quality of services that auditors provide to their clients.

The research question we examine is important because while audit market concentration often is touted as a significant "problem," researchers have not clearly identified the extent (or even the existence) of the problem. In the U.S., a number of parties have expressed concern that the consolidated audit market has a negative impact on audit quality (GAO 2003, 2008). For example, the U.S. Chamber of Commerce and the Center for Audit Quality have proposed that regulators take action to increase competition among auditors (U.S. Chamber of Commerce 2006; Rappeport 2008). Similarly, the U.K.'s Office of Fair Trading (OFT) is concerned that the domination of the U.K. audit market by the Big 4 accounting firms deters competition and is considering possible remedies for this problem (Christodoulou 2011). However, government-mandated studies conducted by the U.S. Government Accountability Office (GAO) have not identified significant issues from the current level of auditor consolidation at the national level (GAO 2003, 2008). The GAO (2008) report acknowledges that the presence of high market shares may not necessarily result in adverse effects, because oligopolistic competition can still be intense and result in favorable situations for audit clients. Thus, the extent to which competition affects audit quality at the local level is an open empirical question with important implications for regulators and audit market participants.

We measure audit market competition from 2000 to 2009 at the metropolitan statistical area (MSA) level. ${ }^{2}$ We focus on the MSA level for a number of reasons. First, although Big 4 auditors dominate the national audit market, the local market shares of individual Big 4 firms vary substantially. Furthermore, non-Big 4 firms that cannot compete effectively with Big 4 firms on a national basis do have a more significant presence in some local markets. Finally, decisions about audit opinions and audit pricing are primarily made at the local office level (Francis et al. 1999; Reynolds and Francis 2000), and variations in auditor expertise and audit quality have also been documented across offices within the same audit firm (e.g., Krishnan 2005; Choi et al. 2010; Francis et al. 2013). All of these factors suggest that the MSA level is the appropriate level for measuring auditor competition. The specific measure of auditor competition that we employ is derived from the Herfindahl index, which is an index that is commonly used in competition studies (GAO 2003, 2008; Kallapur et al. 2010; Boone et al. 2012). This measure captures variation in the number of audit firms present in a local market and the distribution of audit clients among those firms.

We measure audit quality using financial statement restatements, where the subsequent identification of misstatements resulting in a restatement indicates that the engagement auditor performed a lower-quality audit. We focus on restatements rather than accruals-based measures of audit quality for a number of reasons. First, the presence of a restatement is strong evidence that audit quality has been impaired (Palmrose and Scholz 2004). ${ }^{3}$ Further, DeFond et al. (2002) note

\footnotetext{
${ }^{2}$ We exclude observations from 2002 due to the dramatic changes in audit market competition in that year from the demise of Arthur Andersen. Our inferences are unchanged if 2002 is included.

3 Auditors are engaged to provide an opinion on the material accuracy of the financial statements (American Institute of Certified Public Accountants [AICPA] 2001), and a restatement generally indicates an acknowledgement by both the client and the current auditor that the previously issued financial statements were not free from material misstatement.
} 
that earnings management surrogates such as accruals are noisy, indirect measures of the auditor's impact on the client's financial statements, and McNichols (2000) indicates that a gap exists between empirical procedures and our understanding of accruals behavior. Although recent research has improved both our understanding of accruals and the estimation of accrual-based measures of earnings quality (e.g., Hribar and Collins 2002; Kothari et al. 2005; Hribar and Nichols 2007), restatements provide a straightforward proxy for audit quality and have been used as such extensively in the literature (e.g., Kinney et al. 2004; Francis and Michas 2013; Francis et al. 2013; Schmidt 2012; Schmidt and Wilkins 2013). Finally, the widespread occurrence of restatements seems to have been one of the main driving factors behind regulators' recent concern about the quality of financial reporting for U.S. firms (GAO 2006; Securities and Exchange Commission [SEC] 2006). Overall, the use of restatements as a proxy for audit quality is both intuitively appealing and relevant to policymakers.

Contrary to what might be expected based on concerns voiced by regulators and market participants, we find that higher auditor competition is associated with lower audit quality. Specifically, we find that clients located in MSAs with a more competitive audit market are more likely to restate earnings because of a GAAP failure, with the association driven by a higher likelihood of restatements that have a negative net effect (NNE) on the financial statements. ${ }^{4} \mathrm{We}$ do not find any association between auditor competition and the likelihood of restatements that have a positive net effect (PNE) on the financial statements. The relationships we document are economically significant, with firms located in MSAs in the 75th percentile of auditor competition being 13.2 percent more likely to restate their financial statements than firms located in MSAs in the 25th percentile of auditor competition. The economic significance is even stronger among NNE restatements, with firms in the 75th percentile of auditor competition being 16.4 percent more likely to restate than firms in the 25 th percentile.

We conduct several additional analyses to determine how prevalent these findings are across our sample. First, we segregate our sample into clients that are audited by Big 4 auditors and those that are audited by other audit firms in order to investigate whether audit market competition affects both types of audit firms. ${ }^{5}$ Our results hold in both samples; however, we note that the association between competition and restatement is greater for non-Big 4 auditors. Second, we examine whether our results vary by MSA size. We segregate our sample into large MSAs and small MSAs (cutting our sample in half) and find no change in our results. That is, among both large and small MSAs, clients in areas of higher auditor competition are more likely to restate their financial statements. Third, we modify our definition of restatement by imposing restrictions that the restatement's effect on net income exceeds certain thresholds (Francis and Michas 2013). The conclusions associated with these tests are similar to those of the previous tests.

This study makes several important contributions. First, we address a relevant research topic that few others have investigated. Namely, we examine the association between MSA-level auditor competition and audit quality. In light of the findings of the GAO $(2003,2008)$ studies, information regarding the relationship between auditor competition and audit quality is important to both regulators and audit market participants. Second, our study significantly extends recent research dealing with MSA-level competition (Kallapur et al. 2010; Boone et al. 2012) by investigating a

\footnotetext{
4 Audit Analytics codes each restatement according to its effect (positive or negative) on the financial statements. Restatements that have a cumulative effect on net income are coded according to their net effect. Restatements that have no cumulative net effect on income are coded based on their effect to the balance sheet or statement of cash flows, with the overall effect based more heavily on current and operating accounts than on noncurrent accounts. See Appendix B for further discussion of restatement categorization.

5 Our sample period begins in 2000, when there were five large, international auditors. In 2002, Arthur Andersen ceased operations, and there were only four of these audit firms remaining. Throughout the paper, we refer to these firms as Big 4 firms, even during the period when they were the Big 5 .
} 
more direct, "bright line" measure of audit quality-financial statement restatements. Overall, our study complements and extends a recent and growing debate among regulators and researchers about audit market competition and audit quality. Our results lend empirical support to the conclusions of the GAO $(2003,2008)$ studies, which indicate that audit quality does not necessarily suffer in the presence of less competitive audit markets.

The remainder of the paper is organized as follows. The second section presents the study's background and reviews prior literature relevant to the topic. The third section describes the sample and research design. The fourth section reports the results of our empirical tests, and the fifth section describes robustness tests. Finally, the sixth section provides concluding remarks.

\section{BACKGROUND AND HYPOTHESIS DEVELOPMENT}

\section{Audit Firm Consolidation}

Since the late 1980s, a series of events has decreased the number of large, international audit firms from eight to four, causing concern among regulators and audit clients. Their concern is primarily related to (1) decreased competition among the current pool of high-quality auditors as audit market shares become increasingly concentrated, and (2) potential further consolidation of the remaining high-quality audit firms. Regulators and audit clients worry that with lower levels of competition, audit firms could reduce audit quality, because clients with fewer alternatives would be less likely to switch auditors, resulting in less auditor innovation with products and services (GAO 2008). Additionally, dominant audit firms could coordinate actions to increase prices for audit clients (GAO 2008). For example, Ken Lever, chair of the financial reporting committee at The Hundred Group, the club comprised of CFOs from the U.K.'s largest public companies, stated that "if one [large audit firm] disappeared, we'd really have no choice. We would need a regulatory body_God forbid-just to preserve pricing in the market" (Kersnar 2008).

In response to fears about a lack of auditor competition, several agencies have investigated issues related to auditor consolidation. As part of the Sarbanes-Oxley Act of 2002 (SOX), Congress mandated that the GAO study audit firm consolidation and its impact on the audit market. The GAO conducted two studies that examined several topics, including competition, client choice, audit fees, and audit quality (GAO 2003, 2008). In the U.K., the Department of Trade and Industry and the Financial Reporting Council commissioned a similar study on audit market competition (Oxera 2006). The Center for Audit Quality (CAQ) and the U.S. Chamber of Commerce also commented on the situation, with the latter agency noting that limitations set forth by SOX on services that an audit firm is able to provide to its clients essentially imposed further reductions in auditor choice for certain audit clients (U.S. Chamber of Commerce 2006; Rappeport 2008). The Chamber of Commerce has proposed a plan to support greater competition among audit firms (U.S. Chamber of Commerce 2006), and the CAQ has suggested methods to reduce barriers to growth of non-Big 4 firms (Rappeport 2008). Despite these concerns, however, the GAO (2008) report acknowledges that the presence of high market shares may not necessarily result in decreased audit quality, because oligopolistic competition can still be intense and result in favorable situations for audit clients.

\section{Restatements as a Proxy for Audit Quality}

Although audit quality can be defined in several ways, we focus on a variable that measures a failure of the primary responsibility of the auditor. The auditor's responsibility is to "plan and perform the audit to obtain reasonable assurance about whether the financial statements are free of material misstatement, whether caused by error or fraud" (Public Company Accounting Oversight Board [PCAOB] 2003). The required audit effort necessary to determine the material accuracy of 
the financial statements varies with the client's quality of financial statement preparation; however, high-quality audits include sufficient audit effort to support the opinion expressed by the auditor. When an auditor expresses an unqualified opinion on misstated financial statements, it is likely that the auditor's effort was insufficient to support the audit opinion.

Restatements due to failures in the application of GAAP are instances where the auditor and client acknowledge that previous financial statements were not presented in accordance with generally accepted accounting principles. Thus, restatements provide direct evidence that previous financial statement audits were of insufficient quality. ${ }^{6}$ Eilifsen and Messier (2000) explain that failure by the auditor to detect and correct a material misstatement is an antecedent to client restatement. Further, Palmrose and Scholz (2004) state that material restatement is a strong indication of a low-quality audit, and Francis and Michas (2013) note that auditors are partly responsible for allowing a company to issue materially misstated financial statements. For these reasons, and because restatements pose a direct-and highly visible - threat to the public trust regarding the quality of financial reporting, the accounting literature frequently has used restatements as a proxy for low audit quality (e.g., Kinney et al. 2004; Schmidt 2012; Schmidt and Wilkins 2013). ${ }^{7}$

\section{Audit Competition and Audit Quality}

Auditors conduct high-quality audits by exerting sufficient effort to detect misstatements in the financial statements and then reporting any problems that are discovered (DeAngelo 1981). Auditors balance the opposing forces of effectiveness and efficiency when choosing the level of audit effort. If audit clients were willing to pay unlimited audit fees, an auditor could conduct highly effective audits by examining in great detail a client's accounts and transactions (i.e., the auditor would increase effort). However, audit contracts generally have an upper bound on allowable fees, so increased auditor effort (i.e., more hours worked) directly results in lower audit firm profits. To the extent that an audit engagement allows for a greater number of hours, the auditor can conduct a higher-quality audit while preserving expected profits. However, audit contracts that allow fewer audit hours relative to other engagements force the auditor to choose between a reduction in audit effort and a reduction in profit. Thus, auditors face a tradeoff between audit effort and profit, while still adhering to an acceptable level of audit risk.

Auditors have historically competed on both price and quality, but competition has more recently focused on price (Zeff 2003a, 2003b). Mayhew and Wilkins (2003) show that competition based on quality still occurs for national market-leader firms, which may be seen as higher-quality auditors. However, audit firms that have not differentiated themselves as market leaders find it difficult to profit from economies of scale because price competition forces them to share their cost savings with their clients. Our discussions with partners consistently suggest that audit firms have been competing on price during the post-SOX era, and academic research suggests that auditors do, in fact, receive lower audit fees when competition is higher (Chaney et al. 2003; Kallapur et al. 2010; Numan and Willekens 2012). Unlike the consistently negative relationship between competition and fees, however, predictions extending to audit quality can go in either direction.

\footnotetext{
${ }^{6}$ We do not suggest the converse assumption, which is that financial statements that are not restated are evidence of high audit quality. Certainly, some firms present misstated financial statements that are never restated. Our assertion is that, on average, audits associated with financial statements that are acknowledged to be misstated are of lower audit quality than audits associated with financial statements that are not subsequently restated.

7 Previous studies have documented various causes of restatements (Palmrose et al. 2004; Hennes et al. 2008; Plumlee and Yohn 2010); however, the auditor's responsibility relating to the proper representation of the financial statements is constant. Therefore, our empirical tests use all available restatements due to GAAP failures, regardless of the cause of the restatements.
} 
Audit firms that operate in highly competitive markets are likely to work toward client retention. Auditors can improve client relations and increase retention by improving audit efficiency and/or by showing leniency to clients. To the extent that auditors increase efficiency at the expense of effectiveness, there is an increased likelihood that audit effort will not be sufficient to detect material misstatements. Likewise, the fear of client loss can drive auditors to become more lenient with their clients (i.e., independence is impaired), resulting in an increased likelihood that material errors are not reported or corrected. As such, it is reasonable to assume that audit quality will be lower when competition is higher. However, increased competition may result in innovation, which could lead to higher (or at least constant) audit quality. For example, Polimeni et al. (2010) note that competition has influenced audit firms to adopt paperless audit initiatives, and perception among auditors indicates that innovation in this audit technology has improved audit quality (CCH 2008). Higher quality may also exist in markets with low competition, because the reduced fee and turnover pressure in these markets may permit auditors to charge fees that permit more effective audits (i.e., audits that adequately support a given audit opinion) and to take a harder line with their clients. However, it is also possible that lower audit quality may exist in markets with low competition if auditors are not driven to improve, and become lax in their audit procedures. Finally, it is possible that incentives related to reputation, litigation, and compliance with professional standards are sufficient to ensure that competition does not significantly impact audit quality in either direction. Ultimately, this is an empirical question.

Prior research has investigated the relationship between audit quality and auditor competition in other scenarios and found mixed results. Chaney et al. (2003) develop a theoretical model to examine how direct, uninvited solicitation by audit firms affects audit pricing. They show that banning such solicitation imposes "unnecessary costs on clients," and infer that competition among audit firms improves efficiencies in the client-auditor relationship that extend to other forms of competition beyond direct solicitation. Hackenbrack et al. (2000) conduct an empirical study in a market where the auditor bidding process excludes fees. The authors document indirect evidence that restrictions on price competition are associated with higher audit quality. On the other hand, Jeter and Shaw (1995) study a similar research question in a market where a ban on direct, uninvited competition was lifted and find no evidence that competition results in lower auditor independence or lower audit quality. There are more studies that examine how auditor competition affects pricing, although they reach no conclusive end (e.g., Maher et al. 1992; Sanders et al. 1995; Hay and Knechel 2010). Our study differs from previous research because we investigate the impact of the current level of competition in MSA-level audit markets, rather than examining events such as deregulation (e.g., Craswell et al. 1997; Crittenden et al. 2003) or the demise of Arthur Andersen and the Sarbanes-Oxley Act (e.g., Kohlbeck et al. 2008; Hogan and Martin 2009), which affected how auditors compete with one another.

Two recent papers are particularly relevant to our study. First, Kallapur et al. (2010) examine how audit market concentration at the MSA level affects audit quality as proxied by accruals quality. They find that lower competition is associated with higher audit quality and that lower MSA-level competition is associated with higher audit fees. Second, Boone et al. (2012) use a refined sample of firms that are likely to manage earnings, and find that audit clients are more likely to meet or beat earnings targets in areas of lower auditor competition. Although these studies find opposite results, they are important because they focus on auditor competition at the MSA level. Other studies, such as those conducted by the GAO (2003, 2008), examine auditor competition at the national level or national-industry level using an approach primarily based on surveys and interviews.

As mentioned previously, we focus on audit market competition at the local (MSA) level for several reasons. First, measuring audit market competition at the MSA level provides for greater variation in competition (and, hence, potentially more informative tests) than when competition is 
measured at the national level. Second, and more importantly, decisions about audit opinions and audit pricing primarily are made at the local office level (Francis et al. 1999; Reynolds and Francis 2000). Third, the majority of firms are audited by auditors located in the same area (Choi et al. 2012). Finally, studies have found that auditor expertise and audit quality vary across offices within the same firm (e.g., Krishnan 2005; Choi et al. 2010; Francis et al. 2013). We follow this body of literature and examine how competition within an MSA affects the likelihood of client restatements.

\section{Hypothesis}

Our research question examines how auditor competition affects audit quality at the MSA level. As described in the preceding sections, the impact of auditor competition on audit quality is unresolved. Auditors must choose between improving profits and conducting additional procedures because additional audit effort directly reduces audit firm profits. In our view, it is likely that the fee and client retention pressures that exist in areas of high auditor competition will force auditors to decrease audit effort, thereby compromising audit effectiveness. In such cases, it is reasonable to expect an increase in the probability of client restatement. In MSAs with low competition, however, the threat of client switching is lower and auditors may be able to negotiate more favorable contracts. The increased flexibility associated with these contracts may allow for greater audit effort, thereby increasing audit effectiveness and decreasing the probability of client restatement. Both of these scenarios suggest, consistent with Kallapur et al. (2010), a negative relationship between auditor competition and audit quality. However, it is also possible that incentives to protect reputation, minimize litigation risk, and maintain compliance with professional standards are sufficient to cause auditors to consistently provide adequate effort (potentially at the expense of profits) or to refuse engagements where they do not believe that adequate effort can be provided. If this is the case, we would not expect to see any difference in audit quality, regardless of the level of competition (e.g., Jeter and Shaw 1995). Finally, to the extent that decreased auditor competition fosters environments of complacency or tacit auditor collusion (e.g., Shepherd 1997; GAO 2008), a positive relationship may exist between auditor competition and audit quality (e.g., Boone et al. 2012). Because of these contrasting possibilities, we do not make a directional prediction about the relationship between auditor competition and audit quality. Our hypothesis is as follows, in null form:

H1: MSA-level auditor competition is not associated with the probability of client restatement.

\section{RESEARCH DESIGN AND SAMPLE}

\section{Research Design}

We use logistic regression to determine whether MSA-level auditor competition affects the probability of client restatement. Our model is as follows:

RSTMNT_TYPE $=\beta_{0}+\beta_{1} A U D I T_{-} C O M P+\mathbf{X}^{\prime} \boldsymbol{\beta}+\varepsilon$.

Our test variable of interest is AUDIT_COMP, which is the level of auditor competition within an MSA. The dependent variable, RSTMNTT_TYPE (defined three different ways), identifies firms that

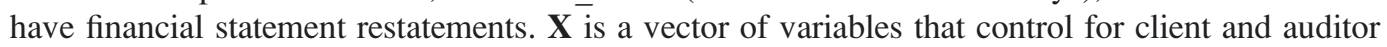
characteristics. The model also clusters standard errors by firm, and controls for year and for the 48 Fama and French (1997) industry fixed effects. We define and discuss our variables below.

\section{Restatements}

While studies have used restatements as a proxy for audit quality in the past (e.g., Kinney et al. 2004; Schmidt 2012; Francis et al. 2013; Schmidt and Wilkins 2013), the literature notes that there 
are several reasons for restatements. Palmrose et al. (2004) and Hennes et al. (2008) classify restatements into those that are intentional and those that are unintentional. Plumlee and Yohn (2010) classify restatements into four categories that include company error, intentional manipulation, transaction complexity, and accounting standard characteristics. Distinguishing among these types of errors is important for some research questions (see Hennes et al. 2008), but we retain all restatements that relate to GAAP failures because auditors' opinions regarding the material accuracy of financial statements should be unaffected by the reason for a misstatement. ${ }^{8}$

We obtain data regarding financial statement restatements from the Audit Analytics Restatement File. ${ }^{9}$ This file provides a general explanation of the reason(s) that a restatement was required, as well as indicating the restated time period(s). As indicated above, we use three different specifications of RSTMNT TYPE in our empirical tests. In our first specification, we create the indicator variable, RESTATEMENT, with a value equal to 1 if any of the restatement period is included within a given firm year, and 0 otherwise. We note that some firms restate the same period multiple times (Files et al. 2012), but we make no distinction for this circumstance, as we are concerned only with whether the financial statements were incorrect when they were first issued. Thus, RESTATEMENT $=1$ for observations where the client and auditor acknowledge that the financial statements were materially misstated during the period of restatement (which is a clear indication that audit quality was impaired).

The Audit Analytics Restatement file indicates that the majority of restatements result in a negative net effect (NNE) on the financial statements, although some restatements do result in a positive net effect (PNE). While our main focus concerns whether the originally issued financial statements included any subsequently acknowledged material errors (i.e., RESTATEMENT $=1$ ), we recognize that liability concerns drive auditors to focus more heavily on overstatements (Nelson et al. 2002; Francis and Michas 2013). Therefore, as additional tests, we also separately consider NNE and PNE restatements. We define NEG_EFFECT (POS_EFFECT) as an indicator variable with a value of 1 when the restatement has a negative (positive) net effect on the financial statements, and 0 otherwise.

\section{Auditor Competition}

The Herfindahl index is a measure of concentration. The GAO $(2003,2008)$ studies use a variation of this measure to determine auditor concentration at the national level. Other studies, such as Kallapur et al. (2010) and Boone et al. (2012), use the Herfindahl index to measure concentration at the MSA level. Our measure of MSA-level competition is also based on the Herfindahl index. The Herfindahl index is calculated as follows:

$$
\text { Herfindahl Index }=\sum_{i=1}^{N}\left[s_{i} / S\right]^{2},
$$

where $N$ is the number of audit firms within an MSA, $s_{i}$ is the size of audit firm $i$ measured in audit fees, and $S$ is the size of the audit market within the MSA measured in total audit fees. The

\footnotetext{
8 The Audit Analytics Restatement file includes some restatements that are not due to failures in the application of GAAP. We include only GAAP-failure restatements because auditors express an opinion about reporting in accordance with GAAP; thus, this type of restatement is most likely an indicator of poor audit quality. One exception to this assumption might relate to the large number of GAAP-failure restatements that occurred in 2005 due to lease accounting. Our inferences are unchanged if we use all restatements identified by Audit Analytics or if we exclude lease-related restatements from our regressions. See Appendix B for further details of restatement types.

9 We use the restated period option in Audit Analytics such that our dependent variable identifies any client fiscal year in which the financial statements were later restated. We focus on the original period to identify years in which the auditor overlooked misstatements (i.e., an indication of lower audit quality), rather than the announcement period, which arguably could indicate higher audit quality.
} 
Herfindahl index captures variation in the number of audit firms present in MSAs, as well as the distribution of audit fees across those firms. The index increases as the number of audit firms equally sharing an audit market decreases. The Herfindahl index also increases as the disparity in audit fees among audit firms increases. Thus, the Herfindahl index would be highest for a market with one audit firm and lowest for a market with numerous firms having similar audit market shares. The Herfindahl index also would be higher in an MSA that has two dominant Big 4 firms than in an MSA that has a fairly equal market distribution among all Big 4 firms. In our sample, the index varies because some MSAs do not have all Big 4 auditors present, some MSAs include one or two dominant Big 4 auditors, and other MSAs have fairly comparable client portfolios for the Big 4 auditors and several non-Big 4 auditors.

Because the Herfindahl index measures auditor concentration, lower values of the index are indicative of higher auditor competition. Our auditor competition variable is AUDIT_COMP. We calculate $A U D I T$ COMP by ranking our sample observations into quintiles based on descending values of the Herfindahl index. ${ }^{10}$ With this specification, AUDIT_COMP is increasing as competition within an MSA is increasing, and decreasing as the audit market becomes more concentrated within a few firms. ${ }^{11}$ We obtain data regarding auditor location and audit fees from Audit Analytics, and we collect MSA information from the U.S. Census Bureau. ${ }^{12}$

\section{Control Variables}

Our vector of control variables includes characteristics of the auditor and characteristics of the client. Because the purpose of our study is to examine the association between auditor competition and audit quality, we control for auditor characteristics that previously have been shown to affect audit quality. OFFICE_SIZE measures the size of the audit office and is calculated as the log of total audit fees charged by the office during year $t$. Recent studies have found that larger offices conduct higher-quality audits (e.g., Francis and Yu 2009; Choi et al. 2010; Francis et al. 2013). CITY_LEADER and NAT_LEADER are the Fama and French (1997) 48 industry audit market leaders at the MSA and national levels. We include both of these measures because prior literature finds that industry expertise improves audit quality (e.g., Balsam et al. 2003; Krishnan 2003; Francis et al. 2005; Romanus et al. 2008; Reichelt and Wang 2010). BIG4 is an indicator variable that is set equal to 1 if the audit firm is one of the Big 4 audit firms, and 0 otherwise. Large, international audit firms have greater resources and better reputations, so we expect their audits to be of higher quality. Finally, AUDIT_FEES is the log of the audit fees paid by the client firm in year $t$, and FEE_RATIO is the firm's payments for nonaudit fees divided by total fees paid (audit plus nonaudit fees). These two variables represent the economic bonding between the client and the auditor, and are included as control variables because (1) a large client may have more leverage in

${ }^{10}$ We use the quintile-ranked version of the Herfindahl index to avoid the potential impact of extreme index values. Our inferences are unchanged if we use a decile ranking. Furthermore, our conclusions do not change when we use raw values of the index, as noted later in the paper.

11 Our sample includes 139 unique MSAs. Each MSA receives a raw Herfindahl index (HI) value each year, although some of the smaller MSAs do not have an observation in every year. The 139 MSAs in our sample provide 949 separate MSA-year HI values. A relatively high percentage of MSAs have a HI of 1.0 (roughly 17 percent over the sample period). However, less than 1 percent of the total firm-year observations come from these highly concentrated MSAs. Our main results are not sensitive to dropping the 214 observations with raw $\mathrm{HI}=1$, or the additional 227 (290) [424] $\{970\}$ observations that have raw HI $>0.8(>0.6)[>0.5]\{>0.4\}$.

12 Metropolitan Statistical Areas are geographic entities defined by the U.S. Office of Management and Budget, and generally consist of one or more counties containing and surrounding an urban center. For additional details, such as city and county components of specific MSAs, please refer to the U.S. Census Bureau's information at: http://www.census.gov/population/www/metroareas/metrodef.html 
negotiations with its auditor (Francis et al. 2013), and (2) a previous study by Kinney et al. (2004) reports that restatements are positively associated with unspecified nonaudit services.

We also create control variables to capture characteristics of the client that might affect the likelihood of restatement. ${ }^{13}$ Because larger clients may have better-developed control systems, we expect that larger clients are less likely to have misstated financial statements. We define the client firm's SIZE as the log of the firm's sales. We also include the square and cube of SIZE (SIZE_SQ and SIZE_CUB) to allow for the possibility that the relationship between restatements and client size is not linear. Francis and Yu (2009) find that debt balances and sales growth are positively related to audit quality, and that audit quality is lower among loss firms. We define LEVERAGE as long-term debt divided by total assets, GROWTH as the percentage change in sales from the prior year to the current year, ACCEL_FILER as an indicator variable equal to 1 for firms that are large accelerated filers, and LOSS as an indicator variable equal to 1 for firms with negative income before extraordinary items in the current year. ${ }^{14} \mathrm{We}$ also include income before extraordinary items divided by total assets as the firm's ROA to capture any effects that profitability has on the likelihood of restatement. We include LITIGATION as an indicator variable set to 1 if the firm operates in a high litigation-risk industry because prior studies indicate that litigation is linked to restatements (Fuerman 1997; Raghunandan et al. 2003). ${ }^{15}$ We include indicator variables for firms' involvement in MERGER or restructuring activity (RESTRUCT) because these transactions often involve accounting issues that are relatively complex. We make no predictions about the association between these last two variables and restatements because auditors may scrutinize complex, nonroutine transactions more heavily. This increased scrutiny may offset the otherwise increased likelihood of restatement that likely would exist due to transaction complexity.

Our next two variables control for the presence of internal control weaknesses $(I C+W E A K)$ and the absolute value of discretionary accruals (DISACC). Based on previous research (e.g., Ashbaugh-Skaife et al. 2007; Richardson et al. 2002; and others), our expectation is that both of these coefficients will be positive. The association between internal control weaknesses and restatements is relatively straightforward, given that the mere presence of a restatement may imply "a breach in the firm's internal control system" (Doyle et al. 2007). The relationship between restatements and discretionary accruals may be due to misreporting incentives, given that managers that have the greatest incentive to misreport will be more likely to engage in earnings management (e.g., Cheng and Warfield 2005; Bergstresser and Philippon 2006). We include measures of stock trading activity (TRADING) and institutional ownership (INST_OWN) to control for investor uncertainty and corporate governance. To the extent that greater trading volume (lower institutional ownership) is indicative of higher misstatement risk, we expect a positive (negative) coefficient for TRADING (INST_OWN). We include dichotomous variables for industries based on Fama and

${ }^{13}$ We follow prior literature and use restatements as a measure of audit quality (e.g., Kinney et al. 2004; Schmidt 2012; Francis et al. 2013; Schmidt and Wilkins 2013). For restatements to be a valid measure of audit quality in this study, we have to assume that across all audit firms, (1) the probability of a client's misstatement before an audit is the same, and (2) the probability of future restatement, given that an audit failed to detect an existing misstatement, is the same. While it is difficult to assess the validity of these two assumptions, we take specific measures to improve their validity. Specifically, we include variables to control for both the probability of misstatement before the audit and the likelihood of future restatement (given that an audit failed to detect an existing misstatement). These variables include internal control weaknesses, management incentives to manage earnings, institutional shareholder monitoring, trading activities, and auditor industry expertise.

14 Our results are not sensitive to defining ACCEL_FILER as all accelerated filers or only as large accelerated filers. Our results are also not sensitive to removing non-accelerated filers and pre-2004 observations.

15 We code the following industries as high litigation risk following Reichelt and Wang (2010): pharmaceuticals (SIC 2833-2836), computers and computer programming (SIC 3570-3577, 7370), electronics and electric equipment (SIC 3600-3674), and retail (SIC 5200-5961). 


\section{TABLE 1}

\section{Sample Selection}

Compustat firms with CIK codes during 2000-2009

Exclude firms not included in Audit Analytics fee and opinions files

Exclude firms missing data required for control variables

Exclude firms from regulated/financial industries or with insufficient data for discretionary accruals

Exclude observations from 2002

Exclude restatements due to reasons other than failure in the application of GAAP

Final Sample

French's (1997) 48 industry classifications and for years based on Compustat fiscal years. All continuous firm-level control variables are winsorized at the first and 99th percentiles.

\section{Sample and Descriptive Statistics}

We obtain data from Compustat and Audit Analytics. Our sample includes the years 2000 through 2009. Table 1 summarizes our sample selection procedure. We begin with all available Compustat firms and then delete observations lacking the identifier (CIK) that allows us to merge Compustat and Audit Analytics data. Next, we delete observations that do not have an audit opinion in Audit Analytics and observations that lack the Compustat data necessary to construct our control variables. Finally, we delete all observations from 2002 because the demise of Arthur Andersen leads to a significant, sudden change in market shares that is not due to competition. The final sample includes 27,043 firm-year observations.

Table 2 displays descriptive statistics for our sample. We group firm-year observations into four categories, with descriptive statistics for each category shown separately in Table 2: (1) a control group of firm-year observations that have not been restated, (2) a group of firm-years that were restated due to a GAAP failure, including both NNE and PNE restatements, (3) a group of firm-years that includes only those GAAP failures classified as NNE, and (4) a group of firm-years that includes only those GAAP failures classified as PNE. Note that GAAP failures represent 15 percent of our sample $[4,087 /(22,956+4,087)]$. While this percentage is higher than might be expected, recall that we assign a value of 1 to RESTATEMENT if the restatement period extends to any portion of the fiscal year. Many of the restatements available through Audit Analytics span multiple reporting periods. If we count each restatement only once, rather than assigning them to the years affected, the percentage of observations with RESTATEMENT $=1$ drops to 6.8 percent. Because we are concerned with audit quality and because our assumption is that any financial statements that have been restated reflect lower audit quality, we conduct our analysis using the initial definition of RESTATEMENT (i.e., each restatement allocated to all affected periods). ${ }^{16}$

Table 2 also shows that more of the restatements result in a negative net effect on the financial statements (83.9 percent of restatements) than a positive net effect (16.1 percent). MSA-level industry leaders audit between 45 and 51 percent of observations in the categories, and national industry leaders audit between 23 and 26 percent of the observations. Big 4 auditors audit between 77 and 80 percent of the sample observations across the categories. The median ratio of nonaudit

16 Our results are robust to either definition of RESTATEMENT. See Table 8 for analysis using the definition of RESTATEMENT that assigns each restatement only to the first year it occurred, rather than to all years affected by the restatement. 


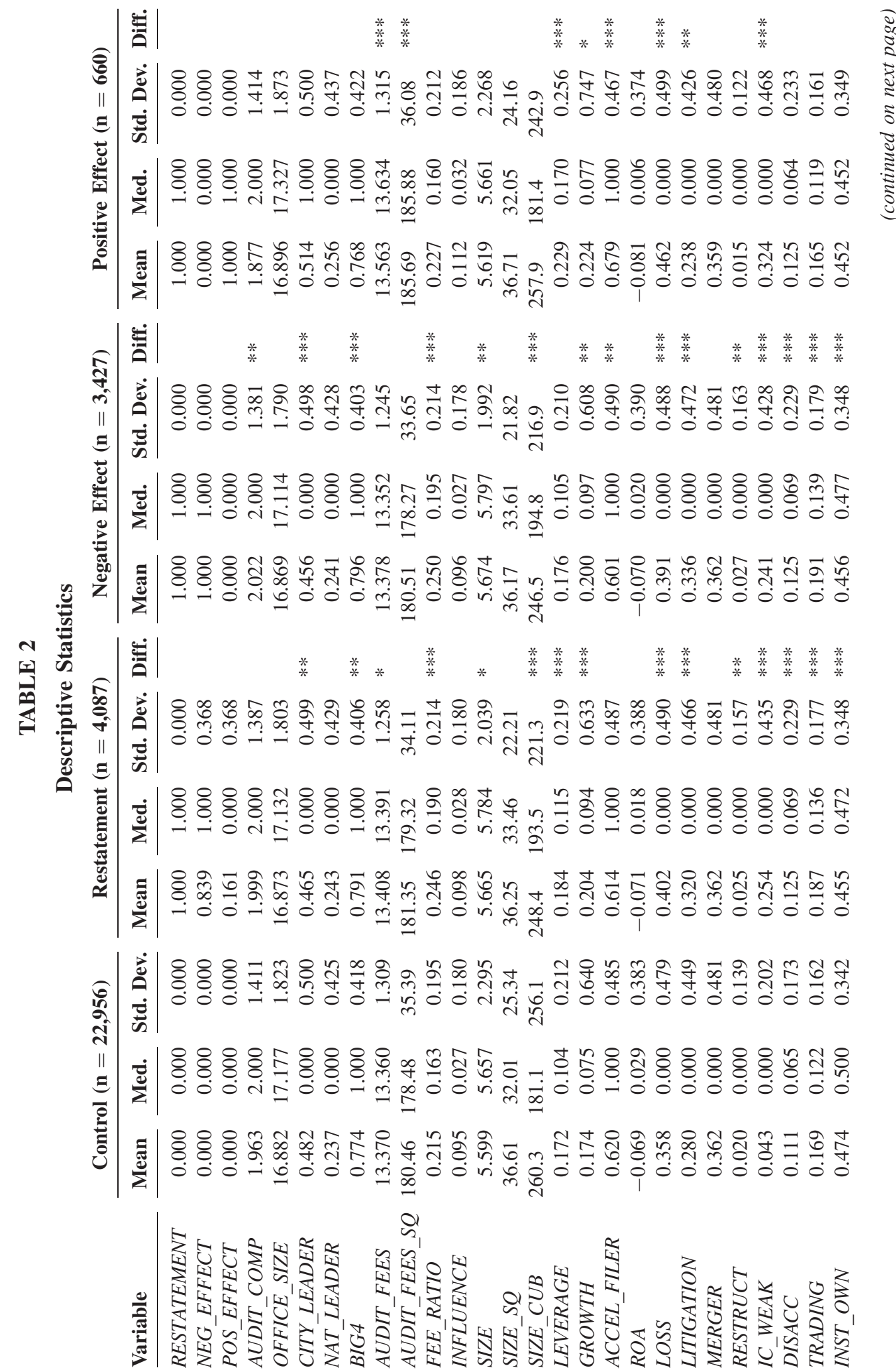




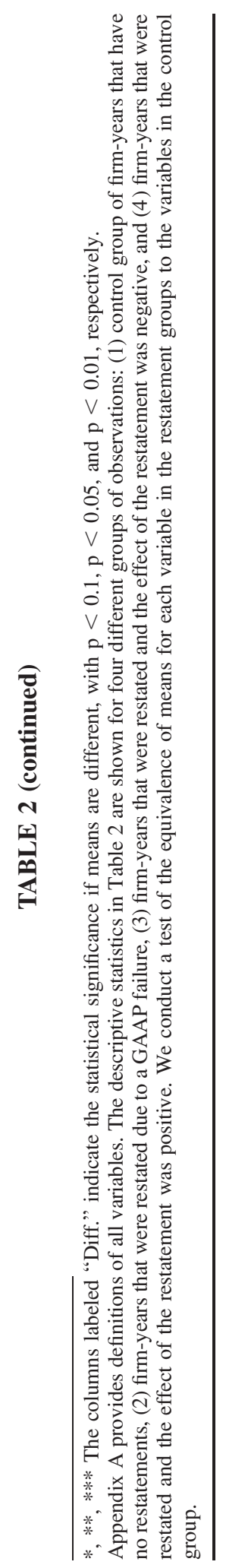


fees to total fees (FEE_RATIO) varies from 16 to 20 percent. The values of these audit-related variables are generally consistent with values in other studies (e.g., Kinney et al. 2004; Choi et al. 2010; Reichelt and Wang 2010; Dunn et al. 2011; Francis et al. 2013). The median ROA for the categories varies from 0.6 percent to 2.9 percent, and the median sales growth varies from 7 to 10 percent. Firms with a loss in the current year make up from 36 to 46 percent of firm-year observations in the observation categories.

We conduct univariate tests regarding the equivalence of variable means between each of the restatement categories and the control group in Table 2. The variable of interest, AUDIT_COMP, is higher in the NNE group than in the control group, providing preliminary evidence that higher competition increases the likelihood of certain types of restatements. OFFICE_SIZE is, on average, smaller for NNE restatement observations, and the percentage of firm-years audited by a CITY_LEADER is lower in the GAAP failure and NNE groups than in the control group. The

FEE_RATIO is higher for GAAP failure and NNE firm-years than for the control group. There are also differences between means of most of the firm-characteristic control variables.

Pearson (Spearman) correlations between variable pairs are shown below (above) the diagonal in Table 3, Panels A and B. Certain control variables are significantly correlated with RESTATEMENT, including industry specialization at the MSA level (negative correlation) and the ratio of nonaudit fees to total fees (positive correlation). Most of the firm characteristics are also significantly correlated with RESTATEMENT. The correlations between NEG_EFFECT and each of the control variables are similar to those of RESTATEMENT, although more of the auditor variables are correlated with $N E G_{-} E F F E C T$ than with RESTATEMENT. Of particular interest to us is the level of auditor competition within the MSA audit market. The variable AUDIT_COMP has a significant, positive correlation with NEG_EFFECT, but AUDIT_COMP is not significantly correlated with POS EFFECT or with the complete set of restatements included in RESTATEMENT. The preliminary findings in Tables 2 and 3 indicate that AUDIT_COMP has an effect on audit quality under certain conditions. We examine these relationships further in the following section. ${ }^{17}$

\section{RESULTS}

\section{Main Results}

We test our hypothesis using the model previously described and present our results from the analysis in Table 4. Table 4 provides three distinct empirical models. The regression in Model (1) uses logistic regression with a dependent variable that indicates the presence of any GAAP failure restatement. The regressions in Models (2) and (3) replace the restatement dependent variable from Model (1) with variables indicating NNE and PNE restatements, respectively.

In Model (1), we document a statistically significant positive coefficient for AUDIT COMP ( $\mathrm{p}$ value $=0.003$ ). Thus, auditor competition at the MSA level increases the likelihood that financial statements will be restated due to GAAP failures. Among the reasons the GAO conducted its studies in 2003 and 2008 was the concern that a lack of auditor competition might reduce audit quality. However, our results show that within the current audit market landscape, MSAs with lower auditor competition have, on average, fewer client restatements. It is important to note that our MSA finding holds in the presence of controls for auditor industry specialization and office size. While we do not find city- or national-level industry specialization to be significantly associated

17 As expected, the correlations among audit fees (AUDIT FEES), audit firm office size (OFFICE SIZE), and client size $(S I Z E)$ are high. To avoid any potential multicollinearity, as a sensitivity analysis, we drop audit fees, audit fees squared, and office size from the models. Our inferences remain the same. 


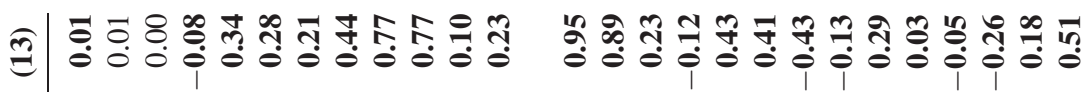
島| 包| 金|

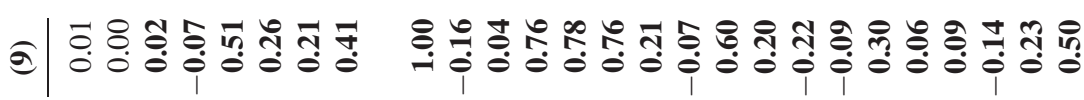
क人 E| Q (n)

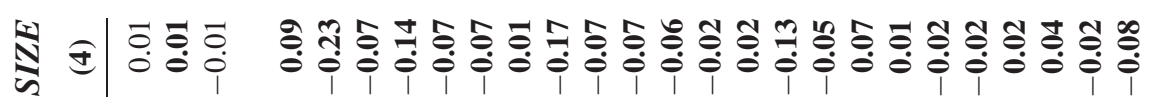

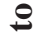

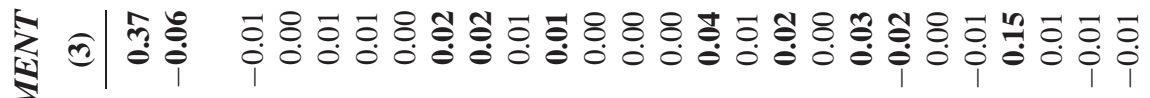
幽

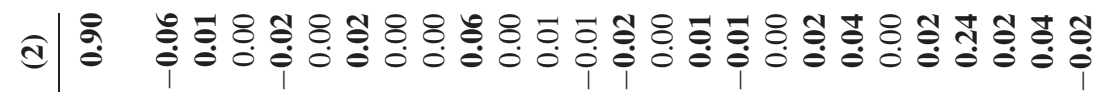
苋

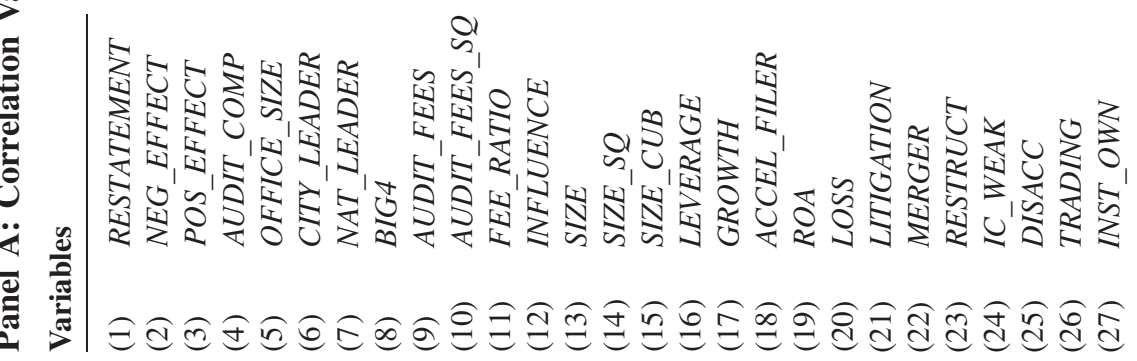




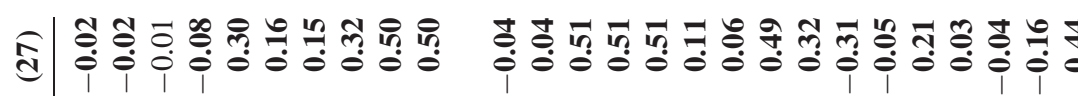

过|

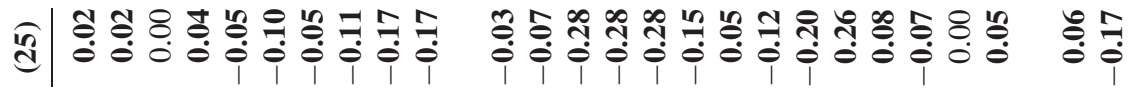

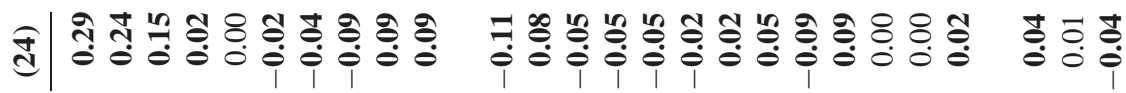

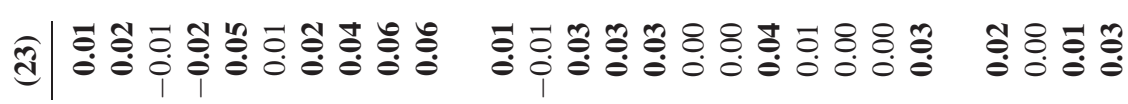

ส্ৰ|

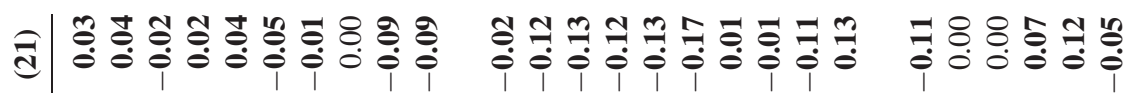

总

享|

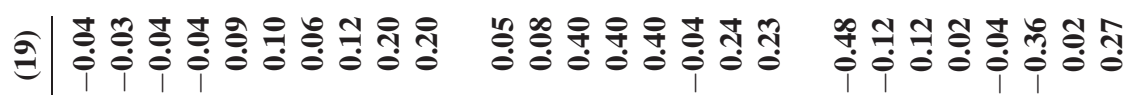

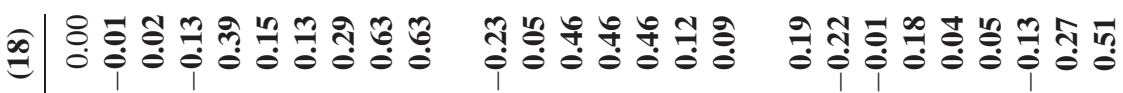

菅

క

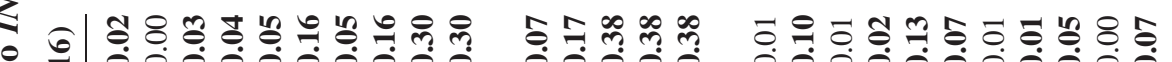
\&

颀

焉

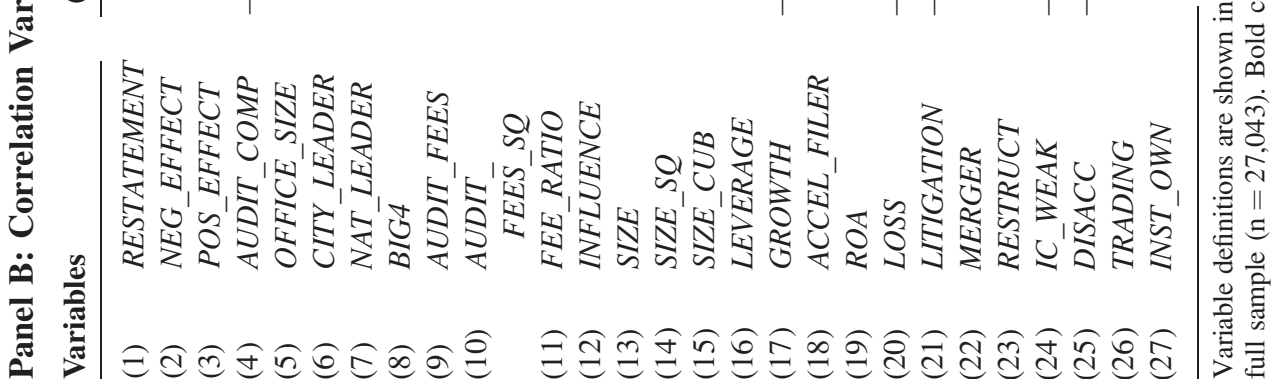




\section{TABLE 4}

\section{Auditor Competition and Restatements}

(1)

Restatement

Variable

\begin{tabular}{l}
\hline AUDIT_COMP \\
OFFICE_SIZE \\
CITY_LEADER \\
NAT_LEADER \\
BIG4
\end{tabular}

AUDIT FEES

AUDIT_FEES_SQ

FEE RATTIO -

INFLUUENCE

SIZE

SIZE SQ

SIZE CUB

LEVERAGE

GROWTH

ACCEL FILER

ROA

LOSS

LITIGATION

MERGER

RESTRUCT

IC WEAK

DISACC

TRADING

INST_OWN

Observations

Pseudo $\mathrm{R}^{2}$

ROC

\begin{tabular}{lcc} 
& & \multicolumn{2}{c}{ Restatem } \\
\cline { 3 - 3 } Pred. & & Estimate \\
+ /- & & $0.062^{* * *}$ \\
- & & $-0.050^{*}$ \\
- & & -0.072 \\
- & & 0.080 \\
- & & 0.078 \\
$+/-$ & -0.157 \\
$+/-$ & 0.010 \\
+ & & $0.497^{* * *}$ \\
$+/-$ & 0.138 \\
- & -0.074 \\
$+/-$ & $0.059^{* * *}$ \\
$+/-$ & $-0.006^{* * *}$ \\
+ & $0.248^{*}$ \\
+ & $0.051^{*}$ \\
- & -0.086 \\
$+/-$ & 0.058 \\
+ & $0.176^{* * *}$ \\
+ & 0.138 \\
$+/-$ & -0.050 \\
$+/-$ & -0.106 \\
+ & $2.141^{* * *}$ \\
+ & $0.264^{* *}$ \\
+ & $0.856^{* * *}$ \\
- & -0.019 \\
& 27,043 \\
& 0.136 \\
& 0.750 \\
\hline
\end{tabular}

(2)

Neg Effect

\begin{tabular}{l} 
p-value \\
\hline$(0.003)$ \\
$(0.083)$ \\
$(0.206)$ \\
$(0.211)$ \\
$(0.426)$ \\
$(0.681)$ \\
$(0.470)$ \\
$(0.000)$ \\
$(0.488)$ \\
$(0.206)$ \\
$(0.000)$ \\
$(0.000)$ \\
$(0.058)$ \\
$(0.083)$ \\
$(0.239)$ \\
$(0.346)$ \\
$(0.002)$ \\
$(0.191)$ \\
$(0.326)$ \\
$(0.403)$ \\
$(0.000)$ \\
$(0.013)$ \\
$(0.000)$ \\
$(0.858)$
\end{tabular}

(0.858)

26,383

0.135

0.754
(3)

Pos Effect

\begin{tabular}{|c|c|c|c|}
\hline Estimate & p-value & Estimate & p-value \\
\hline $0.076 * * *$ & $(0.001)$ & -0.009 & $(0.852)$ \\
\hline$-0.058^{*}$ & $(0.061)$ & -0.010 & $(0.872)$ \\
\hline-0.090 & (0.133) & 0.048 & $(0.721)$ \\
\hline 0.068 & $(0.326)$ & 0.203 & $(0.143)$ \\
\hline 0.123 & $(0.238)$ & -0.074 & $(0.738)$ \\
\hline-0.186 & $(0.646)$ & -0.194 & (0.793) \\
\hline 0.011 & $(0.461)$ & 0.011 & $(0.678)$ \\
\hline $0.408 * * *$ & $(0.006)$ & $0.888 * * *$ & (0.010) \\
\hline 0.129 & $(0.552)$ & -0.002 & (0.996) \\
\hline-0.052 & $(0.431)$ & $-0.171 *$ & (0.094) \\
\hline $0.066^{* * *}$ & $(0.000)$ & 0.024 & $(0.381)$ \\
\hline$-0.006 * * *$ & $(0.000)$ & -0.002 & $(0.440)$ \\
\hline 0.098 & $(0.490)$ & $0.819 * * *$ & $(0.001)$ \\
\hline 0.047 & $(0.152)$ & 0.069 & $(0.212)$ \\
\hline$-0.165^{* *}$ & $(0.036)$ & $0.325^{* *}$ & (0.043) \\
\hline 0.027 & $(0.672)$ & 0.198 & $(0.312)$ \\
\hline $0.130^{* *}$ & (0.033) & $0.358 * * *$ & $(0.005)$ \\
\hline 0.168 & $(0.134)$ & -0.088 & $(0.670)$ \\
\hline-0.042 & $(0.432)$ & -0.019 & $(0.861)$ \\
\hline-0.044 & $(0.736)$ & -0.465 & (0.190) \\
\hline $2.085^{* * *}$ & $(0.000)$ & $2.389 * * *$ & $(0.000)$ \\
\hline $0.241 * *$ & $(0.022)$ & 0.300 & $(0.251)$ \\
\hline $0.991 * * *$ & $(0.000)$ & -0.110 & (0.763) \\
\hline-0.026 & $(0.810)$ & 0.043 & $(0.855)$ \\
\hline 26,383 & & 23,616 & \\
\hline 0.135 & & 0.141 & \\
\hline 0.754 & & 0.771 & \\
\hline
\end{tabular}

$*, * *, * * *$ Represent statistical significance at the $0.10,0.05$, and 0.01 levels, respectively.

This table presents regression results examining the association between auditor competition and client restatements after controlling for other determinants of restatements. Regression models presented in the table use logistic regression and cluster standard errors by firm. Variable definitions are shown in Appendix A. Intercepts and coefficients on year and Fama and French (1997) 48 industry fixed effects are not reported for brevity. 
with restatements, the marginally significant $(\mathrm{p}=0.083)$ negative coefficient for OFFICE_SIZE indicates that restatements are less likely as audit firm office size increases. ${ }^{18}$ This result is consistent with Francis and Yu (2009), Choi et al. (2010), and Francis et al. (2013), who show that audit quality is higher in large audit offices. With respect to our other control variables, we find that clients that have a net loss or that have higher leverage, higher sales growth, or higher nonaudit fees are more likely to have a restatement. ${ }^{19} \mathrm{We}$ also find that restatements are increasing in the square of logged client revenues, indicating that a positive, but nonlinear, relationship exists between restatements and client size. These results are generally consistent with Palmrose and Scholz (2004), Francis and Michas (2013), and Francis et al. (2013).

The Model (2) and Model (3) regressions focus on restatements with negative and positive net effects on the financial statements, respectively. Results for the Model (2) regression are similar to those of the Model (1) regression. Specifically, the coefficients in the NEG_EFFECT regression are generally consistent with the coefficients in the RESTATEMENT regression, and each significant variable in the Model (1) regression remains significant in the Model (2) regression. The results associated with our test hypothesis for the POS_EFFECT regression are not consistent with the results from the other two models. Specifically, $\bar{A} U D I T+C O M P$ is not significantly associated with the likelihood that a client has a PNE restatement. We offer two potential explanations for this result. First, auditors focus on misstatements that overstate income or assets due to liability concerns (Nelson et al. 2002; Francis and Michas 2013). Because understatements (which could result in subsequent PNE restatements) are not auditors' primary focus, it is possible that competition has little effect on auditors' decisions regarding understatements. Second, it is possible that auditor competition does affect the likelihood that auditors discover understatements; however, because auditors are less likely to require management to adjust understatements (Nelson et al. 2002), the effect of auditor competition on PNE restatements is entangled with the auditors' choice to acquiesce to clients' arguments about accounting treatments that lead to lower earnings. In other words, higher competition may result in the discovery of fewer understatements, but auditors may be less likely to consider understatements as material and insist on a contemporaneous adjustment or a subsequent restatement. Most of the other relationships in Model (3) are comparable to the relationships documented in Models (1) and (2), with the notable exception being OFFICE_SIZE, which becomes insignificant.

To summarize, our results show that MSA-level audit market competition is positively associated with the presence of restatements that arise from the misapplication of GAAP. We find that this relationship is most evident for NNE restatements. To the extent that restatements proxy adequately for audit quality, our results indicate that audit quality suffers in markets where auditor competition is higher. This finding is consistent with the results of Kallapur et al. (2010), who find that clients in areas of lower auditor competition have higher accruals quality. The inferences from our tests also have economic significance. In the first model, a change from the 25th to 75th

18 Previous research regarding specialization and the likelihood of restatement is mixed. While both Romanus et al. (2008) and Stanley and DeZoort (2007) document a negative relationship between industry specialization and restatements, Stanley and DeZoort (2007) find that this relationship is limited to short-tenure ( $\leq$ three years) auditor-client relationships. Across all tenure lengths, the relationship between industry specialization and restatement is not significant. Furthermore, both of these papers appear to use restatement announcements as their dependent variable, whereas our dependent variable identifies the restated years. When we use restatement announcements and replicate the model of Stanley and DeZoort (2007), our findings for national specialist auditors are similar to theirs and our inferences for AUDIT_COMP do not change. Our results also do not change when we define industries based on two-digit SIC codes.

19 As an alternative measure of the auditor's dependence on the client (FEE_RATIO), we also include the ratio of client fees to all client fees (as in Chung and Kallapur [2003]). This ratio (INFLUENCE) is not generally significant as a main effect, and is not significant as an interaction with our competition measures (untabulated). FEE RATIO remains positive and significant in most models. 
percentile of auditor competition (AUDIT_COMP values from 1 to 3) results in an increase of 13.2 percent in the likelihood of a restatement. In the second model, the same change in auditor competition results in a 16.4 percent increase in the likelihood of a restatement that impacts the financial statements negatively. ${ }^{20}$ Given the substantial costs associated with restatements (Palmrose and Scholz 2004; Palmrose et al. 2004; Gleason et al. 2008; Wilson 2008), these relationships clearly are non-trivial.

\section{Big 4 and Non-Big 4 Competition}

MSA-level competition may not have the same effect on all auditors within an audit market. Our study examines how audit competition at the MSA level affects audit quality in general in the MSA, but evidence exists to suggest that local audit market competition is bifurcated between Big 4 auditors and lower-tier auditors. For example, survey responses in the GAO (2008) report indicate that many large companies are unwilling to engage midsize and smaller auditors because these audit firms lack the capacity to handle large companies' operations. Prior research also indicates that larger auditors have greater reputations to protect and are less economically dependent on any individual client (e.g., DeAngelo 1981; Reynolds and Francis 2000). Thus, Big 4 auditors may be less susceptible to competitive pressures. Midsize and smaller audit firms, however, have smaller client portfolios and may be more economically dependent on individual clients. In addition, non-Big 4 audit firms do not possess any differential ability that precludes competition from Big 4 audit firms, so non-Big 4 audit clients are potential targets for Big 4 auditors. In order to address these concerns, we examine subsamples of Big 4 and non-Big 4 auditor firms separately.

Table 5 displays separate regressions for firms audited by Big 4 auditors (Panel A) and non-Big 4 auditors (Panel B). In these regressions, AUDIT_COMP is calculated based on the entire audit market, but the regressions are estimated separately for Big 4 and non-Big 4 clients. Based on the discussion in the previous paragraph, the market-level AUDIT_COMP likely reflects competition for midsize and smaller clients because non-Big 4 auditors often lack the capacity to audit large clients. By estimating separate regressions for Big 4 and non-Big 4 auditors, we can determine whether both types of auditors are affected by market-level competition.

The results for AUDIT_COMP in Table 5 are consistent with the results of our main tests in Table 4. In Panel A, we find that audit competition is positively related to all GAAP failure restatements and to the subset of NNE restatements. These results are both statistically and economically significant. For firms audited by a Big 4 auditor (Panel A), the likelihood of a restatement is 9.4 percent higher and the likelihood of an NNE restatement is 10.7 percent higher in the 75th percentile of auditor competition than in the 25th percentile. In Panel B, we again find results that are statistically significant, and the economic results are even stronger. For firms audited by a non-Big 4 auditor, the likelihood of a GAAP failure restatement is 22.4 percent higher and the likelihood of an NNE restatement is 30.2 percent higher in the 75th percentile than in the 25th percentile. Thus, the combined results from Panels A and B in Models (1) and (2) indicate that market-level competition has a stronger economic effect on non-Big 4 firms. However, in both panels, the Model (3) regressions show that the effect of AUDIT_COMP on the likelihood of PNE restatement is insignificant.

${ }^{20}$ The economic significance is calculated as follows: exp(AUDIT_COMP coefficient * AUDIT_COMP 75th percentile value - AUDIT_COMP coefficient $* A U D I T \_C O M P \overline{2}$ th percentile value $)-1$. The values for AUDIT_COMP at the 25th and 75th percentiles are 1 and 3, respectively. For the GAAP failure restatement economic significance: $\exp (0.062 * 3-0.062 * 1)-1=13.2$ percent. For the NNE economic significance: $\exp (0.076 * 3-0.076 * 1)-1=16.4$ percent. 


\section{TABLE 5}

\section{Auditor Competition and Restatements by Auditor Type}

Panel A: Big 4 Firms Sample

(1)

Restatement

\begin{tabular}{l} 
Variables \\
\cline { 1 - 1 } AUDIT_COMP \\
OFFICE_SIZE \\
CITY_LEADER \\
NAT_LEADER \\
AUDIT_FEES \\
AUDIT_FEES_SQ \\
FEE_RATIO \\
INFLUENCE \\
SIZE \\
SIZE_SQ \\
SIZE_CUB \\
LEVERAGE \\
GROWTH \\
ACCEL_FILER \\
ROA \\
LOSS \\
LITIGATION \\
MERGER \\
RESTRUCT \\
IC_WEAK \\
DISACC \\
TRADING \\
INST_OWN
\end{tabular}

Observations

Pseudo $\mathrm{R}^{2}$

ROC

\begin{tabular}{|c|c|}
\hline Pred. & Estimate \\
\hline$+1-$ & $0.045^{*}$ \\
\hline- & -0.015 \\
\hline - & -0.066 \\
\hline- & 0.058 \\
\hline$+1-$ & -0.012 \\
\hline$+1-$ & 0.005 \\
\hline+ & $0.278 *$ \\
\hline$+1-$ & 0.101 \\
\hline- & 0.182 \\
\hline$+1-$ & 0.023 \\
\hline$+1-$ & $-0.004 * *$ \\
\hline+ & 0.176 \\
\hline+ & -0.019 \\
\hline- & -0.082 \\
\hline$+1-$ & 0.049 \\
\hline+ & $0.220 * * *$ \\
\hline+ & 0.125 \\
\hline$+1-$ & -0.085 \\
\hline$+1-$ & -0.174 \\
\hline+ & $2.338 * * *$ \\
\hline+ & 0.224 \\
\hline+ & $0.860 * * *$ \\
\hline- & 0.094 \\
\hline & 21,006 \\
\hline & 0.152 \\
\hline & 0.763 \\
\hline
\end{tabular}

\begin{tabular}{l} 
p-value \\
\hline$(0.058)$ \\
$(0.654)$ \\
$(0.289)$ \\
$(0.377)$ \\
$(0.981)$ \\
$(0.767)$ \\
$(0.083)$ \\
$(0.745)$ \\
$(0.159)$ \\
$(0.383)$ \\
$(0.023)$ \\
$(0.249)$ \\
$(0.653)$ \\
$(0.352)$ \\
$(0.551)$ \\
$(0.001)$ \\
$(0.319)$ \\
$(0.139)$ \\
$(0.212)$ \\
$(0.000)$ \\
$(0.139)$ \\
$(0.000)$ \\
$(0.409)$
\end{tabular}

20,499
(2)

Neg Effect

(3)

Pos Effect

\begin{tabular}{|c|c|c|c|}
\hline Estimate & p-value & Estimate & p-value \\
\hline $0.051 * *$ & $(0.045)$ & 0.012 & $(0.825)$ \\
\hline-0.029 & $(0.426)$ & 0.057 & $(0.474)$ \\
\hline-0.066 & $(0.315)$ & -0.018 & $(0.903)$ \\
\hline 0.044 & $(0.536)$ & 0.214 & $(0.138)$ \\
\hline-0.067 & (0.893) & 0.451 & $(0.662)$ \\
\hline 0.007 & (0.697) & -0.013 & $(0.725)$ \\
\hline 0.155 & $(0.356)$ & $0.866^{* *}$ & $(0.026)$ \\
\hline-0.004 & (0.992) & 0.512 & $(0.423)$ \\
\hline $0.372 *$ & $(0.061)$ & -0.195 & $(0.175)$ \\
\hline 0.004 & $(0.921)$ & 0.026 & $(0.480)$ \\
\hline-0.003 & $(0.143)$ & -0.001 & $(0.583)$ \\
\hline 0.014 & (0.928) & $0.747 * *$ & $(0.015)$ \\
\hline-0.037 & $(0.452)$ & 0.054 & $(0.445)$ \\
\hline-0.144 & (0.128) & 0.301 & (0.149) \\
\hline 0.024 & $(0.770)$ & 0.159 & $(0.490)$ \\
\hline $0.168 * *$ & $(0.015)$ & $0.476^{* * *}$ & $(0.001)$ \\
\hline 0.112 & $(0.396)$ & 0.218 & $(0.383)$ \\
\hline-0.069 & $(0.254)$ & -0.079 & $(0.530)$ \\
\hline-0.072 & (0.611) & $-0.999 * *$ & $(0.031)$ \\
\hline $2.248 * * *$ & $(0.000)$ & $2.716 * * *$ & $(0.000)$ \\
\hline 0.205 & (0.228) & 0.299 & $(0.285)$ \\
\hline $1.000 * * *$ & $(0.000)$ & -0.194 & $(0.661)$ \\
\hline 0.059 & $(0.626)$ & 0.270 & $(0.315)$ \\
\hline
\end{tabular}

18,279

0.176

0.800

Panel B: Non-Big 4 Firms Sample

(1)

Restatement

Variables

AUDIT COMP

OFFICE_SIZE

CITY LEADER

AUDIT FEES

AUDIT_FEES_SQ

FEE RATIO

INFLUENCE

SIZE

SIZE_SQ

$\begin{array}{lll}+/- & & 0.101^{* *} * \\ - & & -0.144^{*} \\ - & & -0.105 \\ +/- & 1.060 \\ +/- & -0.034 \\ + & & 0.998^{* * *} \\ +/- & -0.064 \\ - & -0.142^{*} \\ +/- & 0.046\end{array}$

(2)

Neg Effect

\begin{tabular}{l}
\hline Estimate \\
\hline $0.132^{* * *}$ \\
-0.110 \\
-0.209 \\
0.948 \\
-0.030 \\
$1.050^{* * *}$ \\
0.139 \\
-0.127 \\
0.046
\end{tabular}

(3)

Pos Effect

\begin{tabular}{cccc}
\cline { 1 - 1 } p-value & & Estimate & p-value \\
$(0.004)$ & -0.014 & & $(0.871)$ \\
$(0.175)$ & $-0.303^{* *}$ & $(0.036)$ \\
$(0.205)$ & 0.237 & $(0.383)$ \\
$(0.430)$ & 0.373 & $(0.854)$ \\
$(0.532)$ & 0.000 & $(0.998)$ \\
$(0.002)$ & 0.603 & $(0.433)$ \\
$(0.684)$ & $-1.048^{*}$ & $(0.089)$ \\
$(0.120)$ & $-0.222^{*}$ & $(0.078)$ \\
$(0.147)$ & 0.060 & $(0.214)$
\end{tabular}

(continued on next page) 
TABLE 5 (continued)

(1)

\begin{tabular}{l} 
Variables \\
\hline SIZE_CUB \\
LEVERAGE \\
GROWTH \\
ACCEL_FILER \\
ROA \\
LOSS \\
LITIGATION \\
MERGER \\
RESTRUCT \\
IC_WEAK \\
DISACC \\
TRADING \\
INST_OWN \\
Observations \\
Pseudo R ${ }^{2}$ \\
ROC
\end{tabular}

Restatement

\begin{tabular}{|c|c|c|}
\hline \multirow[b]{2}{*}{ Pred. } & \multicolumn{2}{|c|}{ Restatement } \\
\hline & Estimate & p-valu \\
\hline$+1-$ & -0.004 & $(0.234$ \\
\hline+ & 0.341 & (0.196 \\
\hline+ & $0.110^{* * *}$ & $(0.010)$ \\
\hline- & -0.010 & $(0.942)$ \\
\hline$+1-$ & 0.066 & $(0.466$ \\
\hline+ & 0.045 & $(0.690)$ \\
\hline+ & 0.097 & $(0.608)$ \\
\hline$+1-$ & 0.129 & $(0.250)$ \\
\hline$+1-$ & 0.089 & $(0.800)$ \\
\hline+ & $1.683 * * *$ & $(0.000)$ \\
\hline+ & 0.220 & $(0.155)$ \\
\hline+ & $0.807 * * *$ & $(0.005)$ \\
\hline- & $-0.566 * *$ & $(0.033)$ \\
\hline & $\begin{array}{r}6,037 \\
0.129\end{array}$ & \\
\hline
\end{tabular}

(2)

Neg Effect

\begin{tabular}{ccc}
\hline Estimate & & p-value \\
\cline { 1 - 1 }-0.004 & & $(0.289)$ \\
0.292 & & $(0.335)$ \\
$0.112^{* *}$ & & $(0.014)$ \\
-0.145 & & $(0.331)$ \\
0.040 & & $(0.672)$ \\
0.046 & & $(0.701)$ \\
0.270 & & $(0.164)$ \\
0.080 & & $(0.514)$ \\
-0.236 & & $(0.612)$ \\
$1.684 * * *$ & & $(0.000)$ \\
0.161 & & $(0.246)$ \\
$0.961 * * *$ & & $(0.001)$ \\
-0.479 & & $(0.107)$ \\
5,884 & & \\
0.132 & \\
0.759 &
\end{tabular}

(3)

Pos Effect

\begin{tabular}{ccc}
\hline Estimate & & p-value \\
\cline { 1 - 1 }-0.007 & & $(0.225)$ \\
0.477 & & $(0.263)$ \\
0.108 & & $(0.227)$ \\
0.401 & & $(0.133)$ \\
0.100 & & $(0.718)$ \\
-0.051 & & $(0.823)$ \\
$-0.788^{* *}$ & & $(0.040)$ \\
0.349 & & $(0.140)$ \\
$1.141^{* *}$ & & $(0.031)$ \\
$1.665^{* * *}$ & & $(0.000)$ \\
0.280 & & $(0.486)$ \\
-0.247 & & $(0.702)$ \\
-0.739 & & $(0.110)$ \\
5,337 & \\
0.151 & \\
0.789 &
\end{tabular}

*,**,*** Represent statistical significance at the $0.10,0.05$, and 0.01 levels, respectively.

This table presents regression results examining the association between auditor competition and client restatements for Big 4 and non-Big 4 auditors after controlling for other determinants of restatements. Panel A includes all observations that are audited by Big 4 auditors. Panel B includes all observations that are audited by non-Big 4 auditors. Regression models presented in the table use logistic regression and cluster standard errors by firm. Variable definitions are shown in Appendix A. Intercepts and coefficients on year and Fama and French (1997) 48 industry fixed effects are not reported for brevity. NAT_LEADER is omitted from the non-Big 4 sample because no non-Big 4 auditors are national leaders.

\section{Competition in Large and Small MSAs}

The distribution of auditors is not uniform across all MSAs in our sample. All of the Big 4 auditors are present in some MSAs, while one or more Big 4 auditors are absent in some smaller MSAs. The presence or absence of large auditors likely affects the competitive environment, so we address these differences by partitioning our sample into large and small MSAs. We determine the size of the MSA based on the total audit fees paid by audit clients, and partition our sample into large and small MSA subsamples that are roughly equivalent in number of observations. ${ }^{21}$

Table 6 presents results for the partitioned samples. Panel A displays regressions for the large MSAs. In the large MSA sample, auditor competition is statistically significant ( $p$-value $\leq 0.003$ ) in predicting the likelihood of GAAP failure restatements and NNE restatements. Auditor competition continues to be insignificant for predicting PNE restatements. Panel B displays the results for the small MSA sample. Results for this analysis are similar to those for the large MSA sample, in that higher auditor competition results in a higher likelihood of both GAAP failure restatements and NNE restatements ( $p$-value $\leq 0.04$ ). The results for both large and small MSAs lend further support to our main findings. That is, auditor competition affects the likelihood of misstatements that result in a restatement, and the size of the audit market does not appear to affect this inference.

\footnotetext{
21 Our split of the sample results in the largest 14 MSAs being classified as large MSAs and the remaining 125
} MSAs classified as small MSAs. 
TABLE 6

Auditor Competition and Restatements by MSA Size

Panel A: Large MSA Sample

\begin{tabular}{l} 
Variables \\
\hline AUDIT_COMP \\
OFFICE_SIZE \\
CITY_LEADER \\
NAT_LEADER \\
BIG4 \\
AUDIT_FEES \\
AUDIT_FEES_SQ \\
FEE_RATIO \\
INFLUENCE \\
SIZE \\
SIZE_SQ \\
SIZE_CUB \\
LEVERAGE \\
GROWTH \\
ACCEL_FILER \\
ROA \\
LOSS \\
LITIGATION \\
MERGER \\
RESTRUCT \\
IC_WEAK \\
DISACC \\
TRADING \\
INST_OWN \\
Observations
\end{tabular}

Observations

Pseudo $\mathrm{R}^{2}$

ROC
(1)

Restatement

\begin{tabular}{|c|c|c|}
\hline \multirow[b]{2}{*}{ Pred. } & \multicolumn{2}{|c|}{$\begin{array}{c}\text { (1) } \\
\text { Restatement }\end{array}$} \\
\hline & Estimate & p-value \\
\hline$+1-$ & $0.105^{* * *}$ & $(0.003)$ \\
\hline- & -0.032 & $(0.557)$ \\
\hline- & -0.140 & (0.109) \\
\hline- & $0.238 * * *$ & (0.009) \\
\hline- & 0.135 & $(0.419)$ \\
\hline$+1-$ & -0.501 & $(0.411)$ \\
\hline$+1-$ & 0.019 & $(0.390)$ \\
\hline+ & 0.288 & $(0.186)$ \\
\hline$+1-$ & $0.693^{*}$ & (0.099) \\
\hline- & -0.074 & $(0.382)$ \\
\hline$+1-$ & $0.075 * * *$ & $(0.000)$ \\
\hline$+1-$ & $-0.007 * * *$ & $(0.000)$ \\
\hline+ & $0.451 * *$ & (0.011) \\
\hline+ & $0.073^{*}$ & $(0.073)$ \\
\hline- & -0.069 & $(0.499)$ \\
\hline$+1-$ & 0.045 & $(0.658)$ \\
\hline+ & $0.191 * *$ & $(0.021)$ \\
\hline+ & 0.077 & (0.609) \\
\hline$+1-$ & -0.049 & $(0.512)$ \\
\hline$+1-$ & -0.176 & $(0.310)$ \\
\hline+ & $2.154 * * *$ & $(0.000)$ \\
\hline+ & 0.156 & $(0.306)$ \\
\hline+ & $1.142 * * *$ & $(0.000)$ \\
\hline- & -0.189 & $(0.190)$ \\
\hline & 13,535 & \\
\hline & 0.170 & \\
\hline & 0.786 & \\
\hline
\end{tabular}

(2)

Neg Effect

\begin{tabular}{ccc}
\hline Estimate & & p-value \\
\cline { 1 - 1 } $0.133^{* * *}$ & & $(0.001)$ \\
-0.007 & & $(0.904)$ \\
-0.145 & & $(0.119)$ \\
$0.213^{* *}$ & & $(0.034)$ \\
0.055 & & $(0.753)$ \\
-0.496 & & $(0.449)$ \\
0.019 & & $(0.435)$ \\
0.253 & & $(0.270)$ \\
$0.792^{*}$ & & $(0.074)$ \\
-0.022 & & $(0.817)$ \\
$0.076 * * *$ & & $(0.001)$ \\
$-0.007 * * *$ & & $(0.000)$ \\
$0.346 *$ & & $(0.073)$ \\
$0.074 *$ & & $(0.092)$ \\
-0.135 & & $(0.224)$ \\
-0.065 & & $(0.507)$ \\
0.144 & & $(0.111)$ \\
0.079 & & $(0.620)$ \\
0.001 & & $(0.992)$ \\
-0.055 & & $(0.757)$ \\
$2.076 * * *$ & $(0.000)$ \\
0.100 & $(0.488)$ \\
$1.262^{* * *}$ & $(0.000)$ \\
-0.224 & $(0.147)$ \\
\hline & &
\end{tabular}

13,175

0.166

0.787
(3)

Pos Effect

\begin{tabular}{ccc}
\hline Estimate & & p-value \\
\cline { 1 - 1 }-0.031 & & $(0.665)$ \\
-0.163 & & $(0.169)$ \\
-0.096 & & $(0.587)$ \\
$0.416^{* *}$ & & $(0.024)$ \\
0.577 & & $(0.127)$ \\
-0.582 & & $(0.595)$ \\
0.023 & & $(0.563)$ \\
0.317 & & $(0.504)$ \\
-0.551 & & $(0.510)$ \\
$-0.292^{* *}$ & & $(0.026)$ \\
$0.066^{* *}$ & & $(0.049)$ \\
-0.004 & & $(0.103)$ \\
$0.890^{* *}$ & & $(0.013)$ \\
0.060 & & $(0.435)$ \\
0.208 & & $(0.291)$ \\
$0.831 * *$ & & $(0.016)$ \\
$0.387 * *$ & & $(0.028)$ \\
-0.002 & & $(0.993)$ \\
-0.229 & & $(0.126)$ \\
$-0.823 *$ & & $(0.081)$ \\
$2.476^{* * *}$ & $(0.000)$ \\
0.268 & $(0.473)$ \\
0.347 & $(0.407)$ \\
0.010 & $(0.971)$
\end{tabular}

11,890

0.181

0.810

Panel B: Small MSA Sample

(1)

Restatement

\begin{tabular}{|c|c|c|c|}
\hline \multirow[b]{2}{*}{ Variables } & \multirow[b]{2}{*}{ Pred. } & \\
\hline & & Estimate & p-value \\
\hline AUDIT_COMP & $+1-$ & $0.054 * *$ & $(0.035)$ \\
\hline OFFICE_SIZE & - & -0.056 & $(0.194)$ \\
\hline CITY_LEADER & - & -0.042 & $(0.557)$ \\
\hline NAT_LEADER & - & -0.054 & $(0.504)$ \\
\hline$B I G \overline{4}$ & - & -0.065 & $(0.641)$ \\
\hline AUDIT_FEES & $+1-$ & 0.081 & $(0.883)$ \\
\hline AUDIT_FEES_SQ & $+1-$ & 0.006 & $(0.758)$ \\
\hline FEE_RATTIO & + & $0.710 * * *$ & $(0.000)$ \\
\hline
\end{tabular}

(2)

Neg Effect

\begin{tabular}{l}
\hline Estimate \\
\hline $0.065^{* *}$ \\
-0.049 \\
-0.084 \\
-0.055 \\
0.030 \\
-0.154 \\
0.015 \\
$0.575^{* * *}$
\end{tabular}

(3)

Pos Effect

\begin{tabular}{ccc}
\hline Estimate & & p-value \\
\cline { 1 - 1 } 0.001 & & $(0.984)$ \\
-0.139 & & $(0.206)$ \\
0.245 & & $(0.209)$ \\
-0.000 & & $(0.999)$ \\
-0.366 & & $(0.266)$ \\
1.031 & & $(0.397)$ \\
-0.027 & & $(0.563)$ \\
$1.515^{* * *}$ & & $(0.003)$
\end{tabular}

(continued on next page) 
TABLE 6 (continued)

(1)

Restatement

\begin{tabular}{l} 
Variables \\
\hline INFLUENCE \\
SIZE \\
SIZE_SQ \\
SIZE_CUB \\
LEVERAGE \\
GROWTH \\
ACCEL_FILER \\
ROA \\
LOSS \\
LITIGATION \\
MERGER \\
RESTRUCT \\
IC_WEAK \\
DISACC \\
TRADING \\
INST_OWN
\end{tabular}

Observations

Pseudo $\mathrm{R}^{2}$

ROC

\begin{tabular}{llc} 
Pred. & & Estimate \\
\cline { 1 - 1 }+ /- & & -0.227 \\
- & & -0.071 \\
$+/-$ & & $0.042^{* *}$ \\
$+/-$ & & $-0.004^{* * *}$ \\
+ & & 0.058 \\
+ & & 0.034 \\
- & & -0.096 \\
$+/-$ & 0.088 \\
+ & & $0.158^{* *}$ \\
+ & & 0.156 \\
$+/-$ & -0.057 \\
$+/-$ & -0.040 \\
+ & & $2.157 * * *$ \\
+ & $0.442^{* * *}$ \\
+ & $0.512^{* *}$ \\
- & 0.186
\end{tabular}

13,508

0.118

0.725
(2)

Neg Effect p-value

$\frac{(0.367)}{(0.361)}$

(0.361)

(0.032)

(0.003)

(0.732)

(0.431)

(0.352)

(0.284)

$(0.039)$

(0.251)

$(0.391)$

$(0.823)$

(0.000)

$(0.003)$

$(0.020)$

(0.177)

13,208

\begin{tabular}{c}
\hline Estimate \\
\hline-0.207 \\
-0.073 \\
$0.055^{* *}$ \\
$-0.006^{* * *}$ \\
-0.140 \\
0.024 \\
$-0.188^{*}$ \\
0.106 \\
0.108 \\
0.213 \\
-0.084 \\
-0.039 \\
$2.143^{* * *}$ \\
$0.450^{* * *}$ \\
$0.699^{* * *}$ \\
0.194
\end{tabular}

0.121

0.732
(3)

Pos Effect

\begin{tabular}{ccc}
\hline Estimate & & p-value \\
\cline { 1 - 1 }-0.561 & & $(0.330)$ \\
-0.134 & & $(0.330)$ \\
-0.016 & & $(0.681)$ \\
0.001 & & $(0.678)$ \\
$0.877 * * *$ & & $(0.005)$ \\
0.085 & & $(0.230)$ \\
$0.554^{* *}$ & & $(0.031)$ \\
0.006 & & $(0.972)$ \\
$0.419^{* *}$ & & $(0.015)$ \\
-0.215 & & $(0.492)$ \\
0.215 & & $(0.161)$ \\
-0.114 & & $(0.826)$ \\
$2.252^{* * *}$ & & $(0.000)$ \\
0.344 & & $(0.328)$ \\
-0.917 & & $(0.163)$ \\
0.089 & & $(0.802)$
\end{tabular}

11,726

0.146

0.780

$*, * *, * * *$ Represent statistical significance at the $0.10,0.05$, and 0.01 levels, respectively.

This table presents regression results examining the association between auditor competition and client restatements in different-sized MSAs after controlling for other determinants of restatements. Panel A includes observations found in large MSAs. Panel B includes the remaining observations found in small MSAs. We determine the size of each MSA using the median amount of total audit fees. We divide our original sample such that approximately half of the observations are found in large MSAs and the other half in small MSAs. Regression models presented in the table use logistic regression and cluster standard errors by firm. Variable definitions are shown in Appendix A. Intercepts and coefficients on year and Fama and French (1997) 48 industry fixed effects are not reported for brevity.

\section{Alternative Restatement Definitions}

In this section, we add additional criteria to the restatements identified by Audit Analytics to determine whether auditor competition continues to affect the likelihood of restatement under a more specific definition of a restatement. The Audit Analytics Restatement File identifies restatements as having a positive or negative overall net effect on the financial statements, although the restatement might result in varying effects for the years that are affected. To determine the effect of each misstatement in each year affected by the restatement, we apply a methodology similar to that described by Francis and Michas (2013).

Francis and Michas (2013) use the Compustat Unrestated U.S. Quarterly file to obtain originally reported, as well as restated, income. Their method includes compiling the originally reported net income for each firm for each year in the sample period and comparing the originally reported annual net income to the currently reported data. A difference between the two net income numbers indicates that a restatement may have occurred. They further classify restatements into levels based on the threshold difference in restated net income. For our analysis, we continue to use the Audit Analytics data to identify restatements that occurred, but 
we quantify the magnitude of the restatement using the Francis and Michas (2013) methodology. ${ }^{22}$ First, we partition our restatement sample into three separate levels: restatements that impact net income by 2 percent, 5 percent, or 10 percent. We then estimate separate models for each of these thresholds, with restatements that do not exceed the stipulated threshold being dropped from the sample. Based on our findings from Tables 4-6, and due to the fact that auditors typically are more concerned with income overstatement than understatement (Kothari et al. 1989; Skinner 1994; Basu 1997; Nelson et al. 2002), we conduct separate tests for restatements that have an income effect in either direction and restatements that have only a negative income effect.

Table 7 presents the results for our analysis. For the tests in Panel A, we include restatements that changed net income in either a positive or negative direction by 2 percent (Model 1), 5 percent (Model 2), or 10 percent (Model 3). The results for these tests indicate an effect similar to those documented in our previous tests, regardless of the threshold that is used. Panel B displays a similar analysis, but only restatements that reduce net income and meet the required thresholds are defined as restatements. The results of these tests are again significant, with findings that are similar to our previous tests. In all cases, the coefficient for AUDIT_COMP continues to be positive and significant ( $\mathrm{p}$-value $\leq 0.05$ ). The combined results of Panels $\mathrm{A}$ and $\mathrm{B}$ of Table 7 are consistent with our previous findings and suggest that higher auditor competition results in a higher likelihood of restatement, regardless of the criteria we use to define restatements.

\section{ROBUSTNESS TESTS}

\section{Allocation of Restatement Years}

In our main analyses, we allocated restatements to all years affected by the restatement, which resulted in a high percentage of observations being classified as restated. However, the restatements in subsequent years could be the result of the first year's GAAP application failure even though no new GAAP failure occurs after the first year. Therefore, another option is to assign each restatement only to the first year to which it applies. This alternative treatment reduces the percentage of restated observations to 6.8 percent for our sample of firms. When we reestimate our primary models under this alternative specification (see Table 8), we find a significantly positive coefficient on AUDIT_COMP in the overall restatement test (coefficient $=0.054$, p-value $=0.015)$ and in the NNE test (coefficient $=0.062$, p-value $=0.01$ ), but not in the PNE test. These results are consistent with our initial findings.

\section{Alternative Sample Periods}

Our initial sample consists of the years 2000 through 2009, excluding 2002. We exclude 2002 because one of the Big 5 audit firms, Arthur Andersen, ceased operations in 2002, and we wanted to ensure that our auditor competition measure was not affected by the unique scenarios attributable to the numerous auditor switches that occurred during that year. However, as a sensitivity test, we reestimate our main tests with observations from the year 2002 included. The results for the

\footnotetext{
${ }^{22}$ We use both data sources in this test because the use of Audit Analytics for restatement identification ensures that our restatement observations include only failures in the application of GAAP. However, because Audit Analytics lacks detailed quantitative data about restatements, we use the Compustat data to identify the magnitude of the restatement. The combination of the two datasets provides us with sufficient information to focus our tests on specific restatements.
} 


\section{TABLE 7}

\section{Alternative Definitions of Restatements}

Panel A: Restatements with either Positive or Negative Effects

(1)

2\% Cutoff

Variables

$\overline{A U D I T+C O M P}$

OFFICE_SIZE -

CITY_LEADER -

NAT_LEADER -

$B I G 4$

AUDIT_FEES
AUDIT_FEES_SQ

FEE RATTIO -

INFLUENCE

SIZE $\quad-$

SIZE_SQ

SIZE_CUB

LEVERAGE

GROWTH

ACCEL_FILER

$R O A$

LOSS

LITIGATION

MERGER

RESTRUCT

IC_WEAK

DISACC

TRADING

INST OWN

Observations

Pseudo $\mathrm{R}^{2}$

ROC

23,953

0.203

0.804
(2)

\begin{tabular}{|c|c|c|}
\hline Pred. & Estimate & p-value \\
\hline & $0.063 * *$ & $(0.027)$ \\
\hline- & -0.018 & $(0.662)$ \\
\hline & 0.087 & (0.297) \\
\hline & $0.153^{*}$ & (0.088) \\
\hline - & -0.035 & (0.793) \\
\hline & $-1.044 * *$ & $(0.042)$ \\
\hline & $0.046^{* *}$ & $(0.016)$ \\
\hline+ & $0.434^{*}$ & $(0.062)$ \\
\hline$+1-$ & -0.142 & $(0.630)$ \\
\hline- & $-0.169 * *$ & $(0.025)$ \\
\hline & $0.066 * * *$ & (0.001) \\
\hline$+1-$ & $-0.006 * * *$ & $(0.000)$ \\
\hline+ & $0.450 * *$ & (0.014) \\
\hline+ & 0.065 & $(0.168)$ \\
\hline- & -0.172 & (0.116) \\
\hline$+1-$ & 0.196 & $(0.147)$ \\
\hline+ & $0.211^{* *}$ & $(0.020)$ \\
\hline+ & 0.175 & (0.193) \\
\hline$+1-$ & 0.026 & $(0.737)$ \\
\hline$+1-$ & 0.134 & $(0.496)$ \\
\hline+ & $2.853 * * *$ & $(0.000)$ \\
\hline+ & 0.260 & $(0.129)$ \\
\hline+ & $0.498^{* *}$ & $(0.031)$ \\
\hline & -0.062 & $(0.661)$ \\
\hline
\end{tabular}

5\% Cutoff

$5 \%$ Cutoff

Estimate

$0.069 * * \quad(0.028)$

$-0.019$

0.127

0.140

$-0.052$

$-1.154 * *$

$0.049 * *$

$0.466^{*}$

$-0.240$

$-0.208^{* *}$

$0.077 * * *$

$-0.007 * * *$

$0.538^{* * *}$

0.074

$-0.189$

$0.417 *$

$0.295^{* * *}$

0.150

0.037

0.095

$2.952 * * *$

$0.339 *$

$0.549 * *$

$-0.097$

23,638

0.215

0.823
(3)

$10 \%$ Cutoff

\begin{tabular}{|c|c|}
\hline Estimate & p-value \\
\hline $0.118 * * *$ & $(0.001)$ \\
\hline-0.011 & $(0.825)$ \\
\hline 0.107 & (0.309) \\
\hline $0.219 * *$ & $(0.048)$ \\
\hline-0.032 & $(0.853)$ \\
\hline$-1.149 *$ & $(0.069)$ \\
\hline $0.051 * *$ & $(0.028)$ \\
\hline 0.277 & $(0.348)$ \\
\hline 0.050 & $(0.888)$ \\
\hline$-0.200 *$ & $(0.056)$ \\
\hline $0.084 * * *$ & $(0.001)$ \\
\hline$-0.008 * * *$ & $(0.000)$ \\
\hline $0.679 * * *$ & (0.003) \\
\hline 0.066 & $(0.245)$ \\
\hline$-0.334 * *$ & $(0.015)$ \\
\hline $0.827 *$ & $(0.058)$ \\
\hline $0.404 * * *$ & (0.004) \\
\hline 0.093 & $(0.565)$ \\
\hline 0.042 & $(0.677)$ \\
\hline 0.113 & $(0.646)$ \\
\hline $2.853 * * *$ & $(0.000)$ \\
\hline $0.461 * *$ & $(0.024)$ \\
\hline $0.551 *$ & $(0.055)$ \\
\hline-0.214 & $(0.232)$ \\
\hline
\end{tabular}

23,360

0.206

0.833

Panel B: Restatements with Negative Effects

(1)

2\% Cutoff

\begin{tabular}{l} 
Variables \\
\hline AUDIT_COMP \\
OFFICE_SIZE \\
CITY_LEADER \\
NAT_LEADER \\
BIG4 \\
AUDIT_FEES \\
AUDIT_FEES_SQ \\
FEE_RATIO
\end{tabular}

(2)

$5 \%$ Cutoff

\begin{tabular}{|c|c|c|}
\hline Pred. & Estimate & p-value \\
\hline$+1-$ & $0.062 * *$ & $(0.049)$ \\
\hline- & -0.017 & (0.708) \\
\hline - & 0.107 & $(0.248)$ \\
\hline - & 0.053 & $(0.614)$ \\
\hline - & 0.015 & (0.923) \\
\hline & $-1.160^{* *}$ & $(0.041)$ \\
\hline & $0.048 * *$ & $(0.022)$ \\
\hline+ & 0.204 & $(0.426)$ \\
\hline
\end{tabular}

\begin{tabular}{|c|c|}
\hline Estimate & p-value \\
\hline $0.077 * *$ & $(0.027)$ \\
\hline-0.012 & $(0.807)$ \\
\hline $0.181 *$ & (0.079) \\
\hline 0.074 & $(0.521)$ \\
\hline-0.031 & $(0.855)$ \\
\hline$-1.380 * *$ & (0.017) \\
\hline $0.055^{* *}$ & $(0.010)$ \\
\hline 0.228 & $(0.430)$ \\
\hline
\end{tabular}

(3)

$10 \%$ Cutoff

\begin{tabular}{|c|c|}
\hline Estimate & p-value \\
\hline $0.127 * * *$ & $(0.001)$ \\
\hline-0.018 & $(0.754)$ \\
\hline $0.202 *$ & $(0.085)$ \\
\hline 0.206 & $(0.102)$ \\
\hline-0.119 & $(0.532)$ \\
\hline$-1.355^{* *}$ & $(0.049)$ \\
\hline $0.055^{* *}$ & $(0.029)$ \\
\hline 0.006 & $(0.985)$ \\
\hline
\end{tabular}

(continued on next page) 
TABLE 7 (continued)

(1)

2\% Cutoff

\begin{tabular}{l} 
Variables \\
\hline INFLUENCE \\
SIZE \\
SIZE_SQ \\
SIZE_CUB \\
LEVERAGE \\
GROWTH \\
ACCEL_FILER \\
ROA \\
LOSS \\
LITIGATION \\
MERGER \\
RESTRUCT \\
IC_WEAK \\
DISACC \\
TRADING \\
INST_OWN \\
Observations \\
Pseudo R ${ }^{2}$ \\
ROC
\end{tabular}

\begin{tabular}{l} 
Pred. \\
\hline$+/-$ \\
- \\
$+/-$ \\
$+/-$ \\
+ \\
+ \\
- \\
$+/-$ \\
+ \\
+ \\
$+/-$ \\
$+/-$ \\
+ \\
+ \\
+ \\
-
\end{tabular}

$5 \%$ Cutoff

\begin{tabular}{c}
\hline Estimate \\
\hline-0.096 \\
-0.134 \\
$0.069^{* * *}$ \\
$-0.006^{* * *}$ \\
$0.367^{*}$ \\
0.043 \\
-0.193 \\
0.080 \\
0.166 \\
$0.245^{*}$ \\
0.043 \\
0.187 \\
$2.835^{* * *}$ \\
0.229 \\
$0.703^{* * *}$ \\
0.026 \\
23,575 \\
0.189 \\
0.803
\end{tabular}

(2)

\begin{tabular}{c}
$\mathbf{2}(\mathbf{2})$ \\
$\mathbf{5 \%}$ Cut \\
\hline Estimate \\
\hline-0.222 \\
-0.162 \\
$0.089^{* * *}$ \\
$-0.008^{* * *}$ \\
$0.413^{*}$ \\
0.038 \\
-0.215 \\
0.216 \\
0.193 \\
0.259 \\
0.057 \\
0.160 \\
$3.045^{* * *}$ \\
0.333 \\
$0.843^{* * *}$ \\
-0.086 \\
23,362 \\
0.211 \\
0.828
\end{tabular}

(3)

$10 \%$ Cutoff

23,173

0.203

0.838

*,**,*** Represent statistical significance at the $0.10,0.05$, and 0.01 levels, respectively.

This table reports regression results examining the association between auditor competition and client restatements for three variations of the definition of a restatement. Observations are classified as having a restatement if they are identified as such in the Audit Analytics file and the difference between their unrestated and restated values for net income in Compustat are equal to or greater than the stated threshold ( 2 percent, 5 percent, or 10 percent). Panel A includes all GAAP failures, regardless of the direction of the restatement. Panel B includes only restatements that had a negative effect on net income. Regression models presented in the table use logistic regression and cluster standard errors by firm. Variable definitions are shown in Appendix A. Intercepts and coefficients on year and Fama and French (1997) 48 industry fixed effects are not reported for brevity.

restatement and NNE tests are consistent with our previously reported findings, with coefficients for AUDIT_COMP of 0.065 and 0.075 , and p-values of 0.001 and 0.000 , respectively.

We also consider other time periods that may be of interest. First, we drop all observations before 2003 because the regulatory environment after Sarbanes-Oxley may have reduced the effects of competition on audit quality. Using the sample from 2003 to 2009, we still find significance on AUDIT_COMP in the restatement model (coefficient $=0.062$, p-value $=0.006$ ) and the NNE model (coefficient $=0.079, \mathrm{p}$-value $=0.001) .{ }^{23}$ Second, because it may be of concern that the end of initial sample period does not allow sufficient time for all restatements to be discovered, we eliminate the final two years of our sample. In tests that include only observations between 2003 and 2007, we continue to find significant results for AUDIT_COMP in the restatement model

\footnotetext{
${ }^{23}$ When we divide the sample into two five-year time periods (2000-2004 and 2005-2009), our results are qualitatively unchanged. When we estimate yearly models, our primary NNE results are significant at $\mathrm{p}<0.05$ for five of the years and at $\mathrm{p}<0.10$ for one of the years. One of the four years in which statistical significance is not observed has fewer observations, with only 497 observations occurring in 2000. Using a Fama and MacBeth (1973) approach, the average coefficient for AUDIT_COMP across the ten yearly models is positive $(0.057)$ and statistically significant ( $\mathrm{p}<0.01$ ).
} 


\section{TABLE 8}

\section{Auditor Competition and Restatements Assigned to a Single Year}

(1)

Restatement

Variables

\begin{tabular}{l}
\hline AUDIT_COMP \\
OFFICE_SIZE \\
CITY_LEADER \\
NAT_LEADER \\
BIG4
\end{tabular}

AUDIT FEES

AUDIT_FEES_SQ

FEE RATTIO -

INFLUENCE

SIZE SQ

SIZE CUB

LEVERAGE

GROWTH

ACCEL FILER

ROA

LOSS

LITIGATION

MERGER

RESTRUCT

IC_WEAK

DISACC

TRADING

INST_OWN

Observations

Pseudo $\mathrm{R}^{2}$

ROC
(2)

Neg Effect

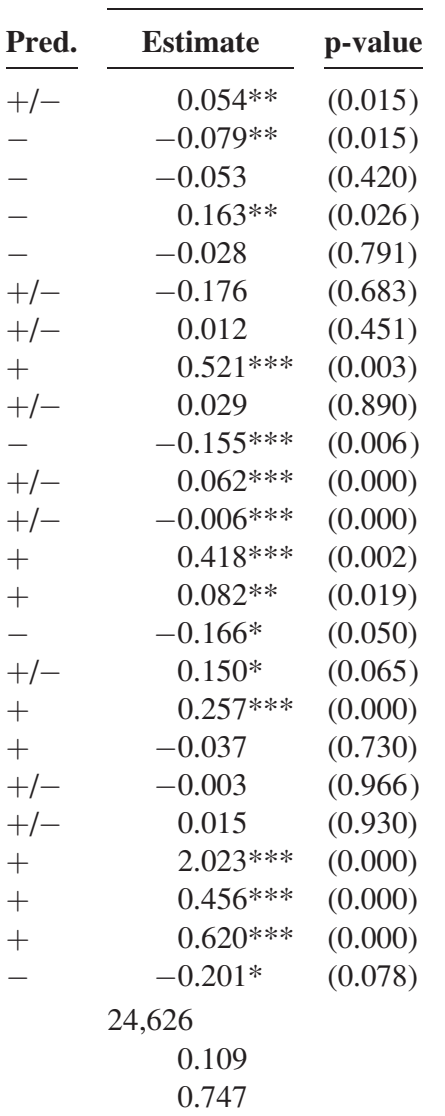

(3)

Pos Effect

\begin{tabular}{|c|c|c|c|}
\hline Estimate & p-value & Estimate & p-value \\
\hline $0.062 * *$ & $(0.010)$ & 0.015 & $(0.770)$ \\
\hline$-0.088 * *$ & $(0.014)$ & -0.039 & $(0.572)$ \\
\hline-0.080 & $(0.253)$ & 0.078 & $(0.590)$ \\
\hline 0.119 & $(0.137)$ & $0.382 * *$ & $(0.014)$ \\
\hline-0.007 & $(0.951)$ & -0.125 & $(0.592)$ \\
\hline-0.066 & $(0.890)$ & -0.723 & $(0.339)$ \\
\hline 0.009 & $(0.635)$ & 0.030 & $(0.291)$ \\
\hline $0.378 * *$ & $(0.043)$ & $1.086^{* * *}$ & $(0.005)$ \\
\hline-0.029 & $(0.900)$ & 0.210 & $(0.625)$ \\
\hline$-0.127^{* *}$ & $(0.047)$ & $-0.268 * * *$ & (0.009) \\
\hline $0.067 * * *$ & $(0.000)$ & 0.038 & $(0.163)$ \\
\hline$-0.006 * * *$ & $(0.000)$ & -0.003 & $(0.194)$ \\
\hline $0.252 *$ & $(0.085)$ & $1.003 * * *$ & $(0.000)$ \\
\hline $0.099 * * *$ & $(0.008)$ & 0.002 & $(0.983)$ \\
\hline$-0.254 * * *$ & $(0.005)$ & 0.249 & $(0.184)$ \\
\hline 0.082 & $(0.308)$ & $0.474 * *$ & $(0.030)$ \\
\hline $0.227 * * *$ & $(0.003)$ & $0.341^{* *}$ & $(0.033)$ \\
\hline-0.052 & $(0.647)$ & 0.027 & $(0.909)$ \\
\hline 0.012 & $(0.860)$ & -0.010 & $(0.941)$ \\
\hline 0.056 & $(0.760)$ & -0.147 & $(0.746)$ \\
\hline $1.958 * * *$ & $(0.000)$ & $2.276^{* * *}$ & $(0.000)$ \\
\hline $0.372 * * *$ & $(0.003)$ & $0.682 * * *$ & $(0.001)$ \\
\hline $0.650^{* * *}$ & $(0.001)$ & 0.394 & $(0.273)$ \\
\hline$-0.214^{*}$ & $(0.081)$ & -0.088 & $(0.721)$ \\
\hline 24,323 & & 23,259 & \\
\hline 0.104 & & 0.117 & \\
\hline 0.749 & & 0.766 & \\
\hline
\end{tabular}

*,**,*** Represent statistical significance at the $0.10,0.05$, and 0.01 levels, respectively.

This table presents regression results examining the association between auditor competition and client restatements using an alternate method of determining the year of the restatement. The Audit Analytics Restatement file gives a range of years affected by a given restatement. All previous tests assigned an indicator variable equal to 1 for all years affected by the restatement. For these regressions, we assign a value of 1 for the restatement indicator variable only in the year the restatement first occurred. Subsequent firm-years of the same restatement are dropped from the analysis. Regression models presented in the table use logistic regression and cluster standard errors by firm. Variable definitions are shown in Appendix A. Intercepts and coefficients on year and Fama and French (1997) 48 industry fixed effects are not reported for brevity. 
(coefficient $=0.061, \mathrm{p}$-value $=0.013)$ and the NNE model (coefficient $=0.073, \mathrm{p}$-value $=0.006)$. Overall, these results indicate that higher auditor competition continues to be a significant predictor of client restatements across a variety of time periods. ${ }^{24}$

\section{Inclusion of Abnormal Audit Fees as a Proxy for Audit Effort}

Our tabulated regressions include the variable AUDIT FEES to control for the total effort exerted by the audit team. The amount of audit fees beyond the level expected based on certain auditor and client attributes may represent additional effort. To control for additional audit effort, we obtain the residuals from the following fee model: AUDIT_FEES $=\beta_{0}+\mathbf{X}^{\prime} \boldsymbol{\beta}+\varepsilon$, where $\mathbf{X}$ is a vector of variables common to fee models, including client size, log of business segments, current assets, liquidity, leverage, return on assets, proportion of foreign sales, going concern opinion indicator, December year-end indicator, loss indicator, material weakness indicator, Big 4 auditor indicator, first-year auditor indicator, and year and industry fixed effects. All of the variables in our model are significant, and the model fits well (adjusted $\mathrm{R}^{2}$ is 0.79 ). We then augment our tabulated results by adding the new variable, ABNORMAL_FEES, to each model.

After controlling for additional auditor effort, the positive association between AUDIT_COMP and restatements continues to be significant. In our main tests, the signs of the coefficients on AUDIT_COMP and the associated p-values are unchanged from the results presented in Table 4. In all of our other tests, the inclusion of ABNORMAL_FEES has only a minor effect, as well. ${ }^{25}$ Thus, our inferences are not sensitive to the inclusion of a proxy for additional audit effort.

\section{Alternative Specification of Auditor Competition}

In our main analyses, we define AUDIT_COMP as the value of the Herfindahl index based on audit fees ranked in descending order. For a final series of robustness tests, we use two other measures of auditor competition. First, we redefine AUDIT_COMP as the raw Herfindahl index times negative one, since other studies such as Kallapur et al. (2010) use the raw index. The results for this test are consistent with our main inferences as reported in Table 4. The coefficient on the raw AUDIT_COMP variable in these tests is 0.51 ( $\mathrm{p}$-value $=0.063$ ) for all restatements, and 0.661 $(\mathrm{p}$-value $=0.035)$ for restatements with negative net effects. We also obtain similar results when we use the Herfindahl index ranked in descending order based on the number of audit clients rather than fees as our measure of competition. For these regressions, the coefficient in the regression using all restatements is 0.06 ( $\mathrm{p}$-value $=0.008$ ), and the coefficient for negative-effect restatements is 0.075 ( $\mathrm{p}$-value $=0.002)$.

\section{CONCLUSION}

Our purpose in this study is to investigate the relationship between auditor competition and audit quality. Our tests indicate that the likelihood of a restatement due to GAAP failure increases

${ }^{24}$ In an additional test, we restrict our analysis to restatements covered by the GAO database (ending in 2005). Our purpose for this test is to be able to isolate (and remove) restatements that were initiated by auditors. Given the presence of an undetected misstatement, a higher-quality auditor is more likely to detect the misstatement and request a restatement. Thus, when auditor-initiated restatements exist, it is less clear that a higher likelihood of restatement is indicative of lower audit quality. However, when we estimate our models during this time period and remove auditor-initiated restatements, our results are qualitatively unchanged.

25 This negligible effect is demonstrated by highlighting the two regressions where the inclusion of ABNORMAL_FEES has the greatest effect on AUDIT_COMP. In Table 5, Panel A, the coefficient (p-value) in the NNE restatement regression changes from 0.051 to 0.050 (p-values: 0.045 to 0.051 ) with the inclusion of ABNORMAL_FEES, and in Table 7, Panel B, the coefficient (p-value) in the $2 \%$ Cutoff regression changes from 0.062 to $0.0 \overline{6} 4$ (p-values: 0.049 to 0.044 ). The coefficient on ABNORMAL_FEES itself is generally positive. 
significantly as auditor competition increases. The economic impact of our findings is significant, as well, with firms located in MSAs in the 75th percentile of auditor competition being 13.2 percent more likely to subsequently restate their financial statements than firms in the 25 th percentile. Further, we find that competition has a greater impact on non-Big 4 audit clients than on Big 4 audit clients. Specifically, non-Big 4 audit clients in the 75th percentile of competition are 22.4 percent more likely to restate than those in the 25th percentile, while the percentage difference for Big 4 clients in these percentiles is only 9.4 percent.

Our study contributes to a growing body of research that examines the relationship between audit quality and a fundamental feature of audit markets: market competition. Our findings add to the discussion documented in the GAO $(2003,2008)$ studies of national-level auditor competition that were based on concerns stemming from the demise of Arthur Andersen. Those studies indicate that audit quality does not seem to be impaired in the current national market. Our tests examine the relationship between auditor competition and audit quality at the local (MSA) level and find that audit quality, as proxied by the existence of restatements, is lower when audit competition is higher. Thus, our results are relevant to the debate about whether consolidation of large CPA firms is likely to impair audit quality.

\section{REFERENCES}

American Institute of Certified Public Accountants (AICPA). 2001. Generally Accepted Auditing Standards. Statement on Auditing Standards No. 95. New York, NY: AICPA.

Ashbaugh-Skaife, H., D. W. Collins, and W. R. Kinney. 2007. The discovery and reporting of internal control deficiencies prior to SOX-mandated audits. Journal of Accounting and Economics 44 (1-2): 166-192.

Audit Analytics. 2011. Data dictionary—Restatements. Available at: http://www.auditanalytics.com/0002/ auditor-restatement.php

Balsam, S., J. Krishnan, and J. S. Yang. 2003. Auditor industry specialization and earnings quality. Auditing: A Journal of Practice \& Theory 22 (2): 71-97.

Basu, S. 1997. The conservatism principle and the asymmetric timeliness of earnings. Journal of Accounting and Economics 24 (1): 3-37.

Behn, B., J. H. Choi, and T. Kang. 2008. Audit quality and properties of analyst earnings forecasts. The Accounting Review 83 (2): 327-359.

Bergstresser, D., and T. Philippon. 2006. CEO incentives and earnings management. Journal of Financial Economics 80 (3): 511-529.

Boone, J. P., I. K. Khurana, and K. K. Raman. 2012. Audit market concentration and auditor tolerance for earnings management. Contemporary Accounting Research 29 (4): 1171-1203.

Bushee, B. J., and C. Noe. 2000. Corporate disclosure practices, institutional investors, and stock return volatility. Journal of Accounting Research 38 (Supplement): 171-202.

$\mathrm{CCH}$. 2008. Transitioning to the next generation of success. CCH Whitepaper. Available at: http://www. cch.com/press/news/CCHWhitepaper_2008Trend.pdf

Chaney, P., D. C. Jeter, and P. E. Shaw. 2003. The impact on the market for audit services of aggressive competition by auditors. Journal of Accounting and Public Policy 22 (6): 487-516.

Cheng, Q., and T. D. Warfield. 2005. Equity incentives and earnings management. The Accounting Review 80 (2): 441-476.

Choi, J-H., J-B. Kim, A. A. Qiu, and Y. Zang. 2012. Geographic proximity between auditor and client: How does it impact audit quality? Auditing: A Journal of Practice \& Theory 31 (2): 43-72.

Choi, J-H., C. Kim, J-B. Kim, and Y. Zang. 2010. Audit office size, audit quality, and audit pricing. Auditing: A Journal of Practice \& Theory 29 (1): 73-97.

Christodoulou, M. 2011. U.K. audit market scrutinized. Wall Street Journal (May 18).

Chung, H., and S. Kallapur. 2003. Client importance, nonaudit services, and abnormal accruals. The Accounting Review 78 (4): 931-955. 
Craswell, A., J. Francis, and S. Taylor. 1997. The Effect of Audit Market Deregulation on the Pricing of Brand Name Reputation. Working paper, University of Queensland, University of MissouriColumbia, and The University of New South Wales.

Crittenden, V., L. Davis, D. Simon, and G. Trompeter. 2003. Deregulation of professional accounting services in the United Kingdom: Integrating marketing and accounting. Journal of Strategic Marketing 11 (1): 37-54.

DeAngelo, L. 1981. Auditor size and audit quality. Journal of Accounting and Economics 3 (3): 183-199.

DeFond, M. L., K. Raghunandan, and K. R. Subramanyam. 2002. Do nonaudit service fees impair auditor independence? Evidence from going concern audit opinions. Journal of Accounting Research 40 (4): $1247-1274$.

Doyle, J., W. Ge, and S. McVay. 2007. Determinants of weaknesses in internal control over financial reporting. Journal of Accounting and Economics 44 (1-2): 193-223.

Dunn, K., M. Kohlbeck, and B. Mayhew. 2011. The impact of the Big 4 consolidation on audit market share equality. Auditing: A Journal of Practice \& Theory 30 (1): 49-73.

Eilifsen, A., and W. F. Messier. 2000. The incidence and detection of misstatements. A review and integration of archival research. Journal of Accounting Literature 19: 1-43.

Fama, E. F., and K. R. French. 1997. Industry costs of equity. Journal of Financial Economics 43 (2): 153193.

Fama, E. F., and J. D. MacBeth. 1973. Risk, return, and equilibrium: Empirical tests. Journal of Political Economy 81 (3): 607-636.

Files, R., N. Y. Sharp, and A. M. Thompson. 2013. Empirical Evidence on Repeat Restatement Firms and Their Auditors. Working paper, The University of Texas at Dallas, Texas A\&M University, and University of Illinois at Urbana-Champaign.

Francis, J. R., and P. Michas. 2013. The contagion effect of low-quality audits. The Accounting Review 88 (2): 521-552.

Francis, J. R., P. N. Michas, and M. Yu. 2013. Office size of Big 4 auditors and client restatements. Contemporary Accounting Research (forthcoming).

Francis, J. R., K. Reichelt, and D. Wang. 2005. The pricing of national and city-specific reputations for industry expertise in the U.S. audit market. The Accounting Review 80 (1): 113-136.

Francis, J. R., D. J. Stokes, and D. Anderson. 1999. City markets as a unit of analysis in audit research and reexamination of Big 6 market shares. Abacus 35 (2): 185-206.

Francis, J. R., and M. Yu. 2009. The effect of Big 4 office size on audit quality. The Accounting Review 84 (5): 1521-1552.

Fuerman, R. D. 1997. Naming auditor defendants in securities class actions. Journal of Legal Economics 7 (1): 72-91.

Gleason, C. A., N. T. Jenkins, and W. B. Johnson. 2008. The contagion effects of accounting restatements. The Accounting Review 83 (January): 83-110.

Hackenbrack, K., K. L. Jensen, and J. L. Payne. 2000. The effect of a bidding restriction on the audit services market. Journal of Accounting Research 38 (2): 355-374.

Hay, D., and W. R. Knechel. 2010. The effects of advertising and solicitation on audit fees. Journal of Accounting and Public Policy 29 (1): 60-81.

Hennes, K., A. Leone, and B. Miller. 2008. The importance of distinguishing errors from irregularities in restatement research: The case of restatements and CEO/CFO turnover. The Accounting Review 83 (6): 1487-1519.

Hogan, C. E., and R. D. Martin. 2009. Risk shifts in the market for audits: An examination of changes in risk for "second tier" audit firms. Auditing: A Journal of Practice \& Theory 28 (2): 93-118.

Hribar, P., and C. Nichols. 2007. The use of unsigned earnings quality measures in tests of earnings management. Journal of Accounting Research 45 (5): 1017-1053.

Hribar, P., and D. W. Collins. 2002. Errors in estimating accruals: Implications for empirical research. Journal of Accounting Research 40 (1): 105-134.

Jeter, D. C., and P. E. Shaw. 1995. Solicitation and auditor reporting decisions. The Accounting Review 70 (2): 293-315. 
Kallapur, S., S. Sankaraguruswamy, and Y. Zang. 2010. Audit Market Concentration and Audit Quality. Working paper, Indian School of Business, National University of Singapore, Singapore Management University.

Kersnar, J. 2008. Mending fences. CFO. Available at: http://cfo.com/article.cfm/10768242/1/c_10792674? $\mathrm{f}=$ search

Khurana, I., and K. Raman. 2004. Litigation risk and the financial reporting credibility of Big 4 versus nonBig 4 audits: Evidence from Anglo-American countries. The Accounting Review 79 (2): 473-495.

Kinney, W. R., Z-V. Palmrose, and S. Scholz. 2004. Auditor independence, nonaudit services, and restatements: Was the U.S. government right? Journal of Accounting Research 42 (3): 561-588.

Kohlbeck, M., B. Mayhew, P. Murphy, and M. Wilkins. 2008. Competition for Andersen's clients. Contemporary Accounting Research 25 (4): 1099-1136.

Kothari, S. P., A. J. Leone, and C. E. Wasley. 2005. Performance matched discretionary accrual measures. Journal of Accounting and Economics 39 (1): 163-197.

Kothari, S. P., T. Lys, C. W. Smith, and R. L. Watts. 1989. Auditor liability and information disclosure. Journal of Accounting, Auditing, and Finance 4: 307-339.

Krishnan, G. V. 2003. Audit quality and the pricing of discretionary accruals. Auditing: A Journal of Practice \& Theory 22 (March): 109-126.

Krishnan, G. V. 2005. Did Houston clients of Arthur Andersen recognize publicly available bad news in a timely fashion? Contemporary Accounting Research 22 (1): 165-204.

Maher, M. W., P. Tiessen, R. Colson, and A. J. Broman. 1992. Competition and audit fees. The Accounting Review 67 (1): 199-211.

Mayhew, B., and M. Wilkins. 2003. The impact of audit firm industry specialization on fees charged to firms going public. Auditing: A Journal of Practice \& Theory 22 (September): 33-52.

McNichols, M. 2000. Research design issue in earnings management studies. Journal of Accounting and Public Policy 19 (Winter): 313-345.

Nelson, M. W., J. A. Elliott, and R. L. Tarpley. 2002. Evidence from auditors about managers' and auditors' earnings management decisions. The Accounting Review 77 (Supplement): 175-202.

Numan, W., and M. Willekens. 2012. An empirical test of spatial competition in the audit market. Journal of Accounting and Economics 53 (1): 450-465.

Oxera. 2006. Competition and Choice in the UK Audit Market. Oxford, U.K.: Oxera Consulting Limited.

Palmrose, Z-V., and S. Scholz. 2004. The circumstances and legal consequences of non-GAAP reporting: Evidence from restatements. Contemporary Accounting Research 21 (1): 139-180.

Palmrose, Z.-V., V. J. Richardson, and S. Scholz. 2004. Determinants of market reactions to restatement announcements. Journal of Accounting and Economics 37 (1): 59-89.

Plumlee, M., and T. L. Yohn. 2010. An analysis of the underlying causes attributed to restatements. Accounting Horizons 24 (1): 41-64.

Polimeni, R. S., J. A. Burke, and D. Benyaminy. 2010. CPA firms going green: The paperless accountant. The CPA Journal 80 (11): 66-71.

Public Company Accounting Oversight Board (PCAOB). 2003. Responsibilities and Functions of the Independent Auditor. Interim Auditing Standards, AU Section 110. Washington, DC: PCAOB.

Raghunandan, K., W. J. Read, and J. S. Whisenant. 2003. Initial evidence on the association between nonaudit fees and restated financial statements. Accounting Horizons 17 (3): 223-234.

Rappeport, A. 2008. Could the lawyers kill the auditors? CFO. Available at: http://cfo.com/article.cfm/ $11661210 ? \mathrm{f}=$ search

Reichelt, K. J., and D. Wang. 2010. National and office-specific measures of auditor industry expertise and effects on audit quality. Journal of Accounting Research 48 (3): 647-686.

Reynolds, J. K., and J. R. Francis. 2000. Does size matter? The influence of large clients on office-level auditor reporting decisions. Journal of Accounting and Economics 30 (3): 375-400.

Richardson, S. A., A. I. Tuna, and M. Wu. 2002. Predicting Earnings Management: The Case of Earnings Restatements. Working paper, London Business School.

Romanus, R. N., J. J. Maher, and D. M. Fleming. 2008. Auditor industry specialization, auditor changes, and accounting restatements. Accounting Horizons 22 (4): 389-413. 
Sanders, G., A. Allen, and L. Korte. 1995. Municipal audit fees: Has increased competition made a difference? Auditing: A Journal of Practice \& Theory 14 (1): 105-114.

Schmidt, J. 2012. Perceived auditor independence and audit litigation: The role of nonaudit services. The Accounting Review 87 (3): 1033-1065.

Schmidt, J., and M. Wilkins. 2013. Bringing darkness to light: The influence of audit quality and audit committee expertise on financial statement restatement transparency. Auditing: A Journal of Practice \& Theory 32 (3).

Securities and Exchange Commission (SEC). 2006. Speech by SEC staff: Remarks regarding restatements before the Financial Executives International meeting. By Scott Taub, Acting Chief Accountant (November 17). Available at: http://www.sec.gov/news/speech/2006/spch111706sat.htm

Shepherd, W. 1997. The Economics of Industrial Organization. Fourth Edition. Upper Saddle River, NJ: Prentice Hall.

Skinner, D. J. 1994. Why firms voluntarily disclose bad news. Journal of Accounting Research 32 (1): 38-60.

Stanley, J. D., and F. T. DeZoort. 2007. Audit firm tenure and financial restatements: An analysis of industry specialization and fee effects. Journal of Accounting and Public Policy 26: 131-159.

U.S. Chamber of Commerce. 2006. Auditing: A Profession at Risk. Washington, DC: U.S. Chamber of Commerce.

U.S. General Accounting Office (GAO). 2003. Public Accounting Firms: Mandated Study on Consolidation and Competition. GAO-03-864. Washington, DC: GAO.

U.S. Government Accountability Office (GAO). 2006. Report to the ranking minority member. Committee on Banking, Housing, and Urban Affairs, U.S. Senate. Washington, DC: GAO.

U.S. Government Accountability Office (GAO). 2008. Audits of Public Companies: Continued Concentration in Audit Market for Large Public Companies Does Not Call for Immediate Action. GAO-08-163. Washington, DC: GAO.

Wilson, W. 2008. An empirical analysis of the decline in the information content of earnings following restatements. The Accounting Review 83 (2): 519-548.

Zeff, S. 2003a. How the U.S. accounting profession got where it is today: Part I. Accounting Horizons 17 (3): 189-205.

Zeff, S. 2003b. How the U.S. accounting profession got where it is today: Part II. Accounting Horizons 17 (4): 267-286.

\section{APPENDIX A}

\section{Variable Definitions}

Dependent Variables

RSTMNT TYPE $=$ One of three different specifications of a financial statement restatement, as described in the definitions of the next three variables.

RESTATEMENT $=$ An indicator variable equal to 1 if the firm's financial statements in year $t$ were restated due to a GAAP failure, as identified in the Audit Analytics

Restatements file.

$N E G_{-} E F F E C T=$ An indicator variable equal to 1 if the firm's financial statements in year $t$ were restated due to a GAAP failure and the restatement effect was negative, as identified in the Audit Analytics Restatements file.

POS_EFFECT = An indicator variable equal to 1 if the firm's financial statements in year $t$ were restated due to a GAAP failure and the restatement effect was positive, as identified in the Audit Analytics Restatements file.

$X \%$ CUTOFF $=$ An indicator variable equal to 1 if the firm's financial statements in year $t$ were restated by at least as much as the given cutoff ( 2 percent, 5 percent, or 10 percent) due to a GAAP failure. Restatement firms are identified from the Audit Analytics Restatements file. The amount of the restatement is determined by comparing unrestated net income reported in the Compustat Unrestated U.S. Quarterly database to restated net income in Compustat.

(continued on next page) 


\section{APPENDIX A (continued)}

Test Variables

AUDIT_COMP $=$ The level of competition within the MSA in year $t$. This variable is the pooled sample's descending-order ranking of the Herfindahl index (HI), which is the sum of the squares of the ratios of each audit firm's size to the total size of the audit market: $\mathrm{HI}=\sum_{i=1}^{N}\left[s_{i} / S\right]^{2}$, where $N=$ number of audit firms in the market, $s_{i}$ is the size of the audit firm, and $S$ is the size of the audit market (in terms of audit fees). For a given number of audit firms, AUDIT_COMP is higher when the audit firms' shares are equal or similar. If all firms are of equal size, AUDIT_COMP is higher when $N$ is large.

Control Variables
OFFICE_SIZE
CITY_LEADER
NAT_LEADER
BIG4
AUDIT_FEES
AUDIT_FEES_SQ
FEE_RATIO
INFLUENCE
SIZE
SIZE_SQ
SIZE_CUB
LEVERAGE
GROWTH
ACCEL_FILER
ROA
LOSS

LITIGATION= An indicator variable equal to 1 if the firm operates in the following risk-oflitigation industries (by SIC code): 2833-2836, 3570-3577, 3600-3674, 52005961, or 7370 .

MERGER = An indicator variable equal to 1 if the firm has acquisition expenses during the year (AQC $>0)$.

RESTRUCT = An indicator variable equal to 1 if the firm has restructuring charges during the year $(\mathrm{RCP}>0)$.

IC_WEAK = An indicator variable equal to 1 if the firm reported a material weakness under Section 302 or 404.

DISACC $\quad=$ The absolute value of discretionary accruals estimated using a performanceadjusted modified Jones model (Kothari et al. 2005).

TRADING = The average monthly percentage of the firm's shares traded (shares traded/shares outstanding) during year $t$.

INST_OWN $\quad=$ The percentage of the firm's shares owned by institutional owners following Bushee and Noe (2000). 


\section{APPENDIX B}

\section{Discussion and Examples of Restatements}

The analysis described in this paper relies on restatement data from Audit Analytics. We focus on restatements resulting from failures in the application of GAAP. Audit Analytics also identifies restatements due to fraud and irregularities, accounting and clerical errors, and other significant issues. We delete 192 restatement observations attributable solely to causes other than GAAP failure. The following table demonstrates the distribution of observations in our sample relating to each restatement cause. Note that some restatements are attributed to several causes.

\begin{tabular}{|c|c|c|c|c|}
\hline Restatements & GAAP & Fraud & Error & Other \\
\hline Total firm-years & 4,087 & 157 & 140 & 387 \\
\hline Firm-years not due to GAAP failure & - & 80 & 105 & 41 \\
\hline Final sample: GAAP failures & 4,087 & 77 & 35 & 346 \\
\hline
\end{tabular}

We also examine subsets of GAAP-failure restatements based on the net effect on the financial statements-restatements that have either a negative net effect (NNE) or a positive net effect (PNE). The determination of the net effect on the financial statements relies on two Audit Analytics data fields, as follows:

- Cumulative Change in Net Income-This data item is the "sum of changes in net income for all the periods affected by the restatement" (Audit Analytics 2011, 4).

- Net Effect on the Financial Statements-This data item "indicates whether the net effect to the financial statements (income statement, balance sheet or cash flows) was positive or negative" (Audit Analytics 2011, 4).

Restatements with either a negative or positive cumulative income statement effect are coded according to this effect. For restatements that do not affect income (such as reclassifications), Audit Analytics considers how investors might interpret the overall effect. The Audit Analytics assessment generally weights the effects to current accounts, operating cash flows, and certain ratios higher than the effects to noncurrent accounts. For example, a restatement that reclassifies an asset from current to long-term would have a negative impact on the current ratio, and would be coded as a negative restatement.

We use a total of 2,287 restatements due to GAAP failures that apply to 4,087 firm-year observations in our sample. The distribution of these GAAP failures by overall net effect to the financial statements and cumulative effect on net income is shown in the table below:

\begin{tabular}{|c|c|c|c|}
\hline Cumulative Effect on Net Income & Any Net Effect & Negative & Positive \\
\hline Negative & 959 & 959 & - \\
\hline Positive & 310 & - & 310 \\
\hline Zero & 560 & 521 & 39 \\
\hline Not coded & 458 & 428 & 30 \\
\hline Total & 2,287 & 1,908 & 379 \\
\hline
\end{tabular}

Note that the cumulative effect on net income is not given for a significant number of restatements. Audit Analytics does not compile this information for firms not traded on major equity exchanges. However, Audit Analytics does provide the net effect categorization for these restatements. The table below provides examples of specific restatements from the categories above, as well as non-GAAP-related restatements. 


\section{Examples of Restatements due to GAAP Failures}

The GAP, Inc. (excerpt from Form 8-K, March 4, 2005)—“AAs disclosed in the February 24, 2005 press release of The Gap, Inc. ... the Company has re-evaluated its lease accounting practices ... Management and the Audit and Finance Committee of the Board of Directors of the Company concluded on March 4, 2005 that the Company's ... financial statements for the two fiscal years ended January 31,2004 , the three interim quarters of fiscal year 2004, and the four quarters of fiscal year 2003 should be restated to correct its accounting for leases, and that such previously filed financial statements should no longer be relied upon ... The effects of the 2004 adjustment and the cumulative effects of the prior period restatements result in a reduction of net income on a pre-tax basis estimated at approximately $\$ 200$ million."

McAfee, Inc. (excerpt from Form 8-K, March 9, 2004)—“' On March 9, 2004, the Company filed with the SEC its Form 10-K for the year ended December 31, 2003. In connection with the preparation of its $200310-\mathrm{K}$, the Company has made corrections to its previously filed or announced quarterly and full year 2003 financial information (reflected in Item 8 of the 2003 Form 10-K that sets forth 2003 quarterly information). In total, these adjustments increased 2003 revenue by $\$ 3.8$ million to $\$ 936.3$ million, 2003 net income by $\$ 3.7$ million to $\$ 70.2$ million and 2003 earnings per share, or EPS, by $\$ 0.03$ to $\$ 0.44$ (basic) and $\$ 0.43$ (diluted). During the preparation and analysis of the Registrant's 2003 consolidated financial statements, the Company identified and reported to PricewaterhouseCoopers, its external auditors, and audit committee required corrections to its previously reported or announced financial information relating to the Company's booking of international deferred revenue and the making of manual journal entries."

Symantec Corp. (excerpt from news release, December 15, 2005)"Symantec Corp. (Nasdaq: SYMC) today announced that it will correct a misclassification in the company's Condensed Consolidated Statements of Cash Flows for the six months ended Sept. 30, 2005 and misclassifications in the Condensed Consolidated Statements of Operations for the three months and six months ended Sept. 30, 2004 and 2005. These classification errors have no impact on the company's previously reported total revenue, earnings, cash and cash equivalents, the Condensed Consolidated Balance Sheets, or previously issued guidance.

On Dec. 14, 2005, the company and its audit committee concluded that the company's Condensed Consolidated Financial Statements for the three and six months ended Sept. 30, 2004 and 2005 should be corrected ... As a result, Cash Flows from Operating Activities will change from $\$ 674$ million to $\$ 529$ million and Cash Flows from Financing Activities will change from $\$(2,236)$ million to $\$(2,091)$ million. Ending cash and cash equivalents remains unaffected at $\$ 1,806$ million."

$\begin{array}{cc}\begin{array}{c}\text { Cumulative } \\ \text { Effect on } \\ \text { Net Income }\end{array} & \begin{array}{c}\text { Net Effect } \\ \text { on Financial } \\ \text { Statements }\end{array} \\ \text { Negative } & \text { Negative }\end{array}$

Positive

Positive

None Negative 
Dollar General (excerpt from 10-K for year ended February 2, 2007)"The Company has historically classified self-insurance and deferred rent liabilities within Accrued expenses and Other, which is included in Total current liabilities on the Company's consolidated balance sheets. Management has concluded that a portion of these liabilities (including approximately $\$ 89.3$ million and $\$ 23.0$ million of selfinsurance and deferred rent liabilities, respectively) and certain other assets of $\$ 15.8$ million and liabilities of $\$ 18.3$ million should be classified as noncurrent, along with the related deferred income tax impacts, where applicable. As a result, the Company has restated the accompanying February 3, 2006 consolidated balance sheet to correct the prior presentation."

No Cumulative Effect on Net Income Coded-The net effect of these restatements is coded following the same methods as those previously listed; however, the cumulative effect on net income is not provided. Audit Analytics indicates this occurs primarily because these firms are not traded on major exchanges. For example, Toys $\mathrm{R}$ Us announced a restatement on May 15, 2007. Toys R Us is a private company that has continued to file its financial statements with the SEC subsequent to going private in 2005. As another example, Land O'Lakes announced a restatement on March 20, 2009. Land O'Lakes filed its financial statements with the SEC due to its publicly traded debt (this debt was extinguished in 2009 and Land O'Lakes no longer files public financial statements).

\section{Examples of Restatements not Identified as GAAP Failures (Excluded from our Sample)}

Oracle Systems (excerpt from 10-K for year ended May 31, 2003)"in the year ended May 31, 2003 we changed the composition of our reportable segments and the amounts in the disclosures for reportable segments for the year ended May 31, 2001 have been restated to conform to the 2003 composition."

Harley-Davidson (excerpt from form 10-K/A for the year ended December 31, 2008) - "This Form 10-K/A is being filed to amend certain historical disclosure items contained within Item 6, 'Selected Financial Data' in the Annual Report on Form 10-K of HarleyDavidson, Inc. (the 'Company') for the year ended December 31, 2009 (the 'Form 10-K'). Specifically, income from continuing operations and net income for the years ended 2006 and 2005 were inadvertently reported as $\$ 1,597,153,000$ and $\$ 1,464,962,000$, respectively, in the selected financial data contained in Item 6 of the recent Form 10-K filed on February 23, 2010. These numbers are actually the income from operations for those years before the effects of investment income and income tax provisions. The correct income from continuing operations and net income for the years ended 2006 and 2005 are $\$ 1,043,153,000$ and $\$ 959,604,000$, respectively ... These numbers were correctly reported in all prior Annual Reports on Form 10-K of the Company for 2005 through 2008, where applicable."
None Positive

Not Coded Negative or Positive

Type of Restatement

Change in presentation

Clerical error on rolledforward disclosures 
U.S. Wireless Corporation (excerpt from Form 10-QSB/A filed July 12, Employee theft/fraud 2001) - "In May 2001, the Company announced that it had completed an investigation that resulted in the termination of the Company's former Chief Executive Officer and the resignation of the Company's former General Counsel. The investigation revealed several transactions in which stock or options to purchase common stock had been issued to various entities without evidence of Board of Directors approval of the transactions, or evidence that the Company had received consideration for the issuance of the stock and options ... Upon further analysis of the transactions ... the issuances of stock and stock options that were the subject of the investigation were determined to have been unauthorized stock issuances. Accordingly, the Company has recorded a non-cash loss from unauthorized stock issuances." 